\title{
Groundwater Calculations for Depleted Uranium Disposed of as Uranium Tetrafluoride $\left(\mathrm{UF}_{4}\right)$
}

Environmental Assessment Division Argonne National Laboratory

Operated by The University of Chicago,

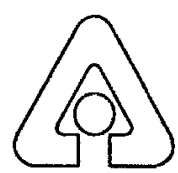
under Contract W-31-109-Eng-38, for the

\section{United States Department of Energy}




\section{Argonne National Laboratory}

Argonne National Laboratory, with facilities in the states of Illinois and Idaho, is owned by the United States Government and operated by The University of Chicago under the provisions of a contract with the Department of Energy.

This technical memorandum is a product of Argonne's Environmental Assessment Division (EAD). For information on the division's scientific and engineering activities, contact:

Director, Environmental Assessment Division

Argonne National Laboratory

Argonne, Illinois 60439-4832

Telephone (630) 252-3107

Presented in this technical memorandum are preliminary results of ongoing work or work that is more limited in scope and depth than that described in formal reports issued by the EAD.

Publishing support services were provided by Argonne's Information and Publishing Division (for more information, see IPD's home page: http://www.ipd.anl.gov/).

\section{Disclaimer}

This report was prepared as an account of work sponsored by an agency of the United States Government. Neither the United States Government nor any agency thereof, nor The University of Chicago, nor any of their employees or officers, makes any warranty, express or implied, or assumes any legal liability or responsibility for the accuracy, completeness, or usefulness of any information, apparatus, product, or process disclosed, or represents that its use would not infringe privately owned rights. Reference herein to any specific commercial product, process, or service by trade name, trademark, manufacturer, or otherwise does not necessarily constitute or imply its endorsement, recommendation, or favoring by the United States Government or any agency thereof. The views and opinions of document authors expressed herein do not necessarily state or reflect those of the United States Government or any agency thereof, Argonne National Laboratory, or The University of Chicago. 
ANL/EAD/TM-111

Groundwater Calculations for Depleted Uranium Disposed of as Uranium Tetrafluoride $\left(\mathrm{UF}_{4}\right)$

by D. Tomasko

Environmental Assessment Division

Argonne National Laboratory, 9700 South Cass Avenue, Argonne, Illinois 60439

July 2001

Work sponsored by U.S. Department of Energy, Office of Nuclear Energy, Science and Technology 
This report is printed on recycled paper. 


\section{CONTENTS}

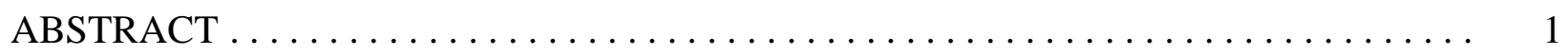

$1 \quad$ INTRODUCTION $\ldots \ldots \ldots \ldots \ldots \ldots \ldots \ldots \ldots \ldots \ldots \ldots \ldots \ldots \ldots \ldots$

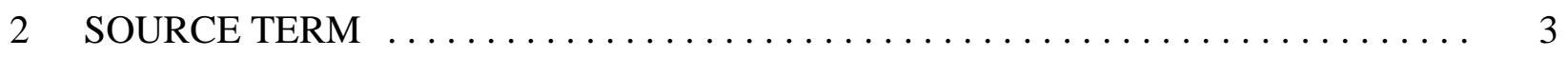

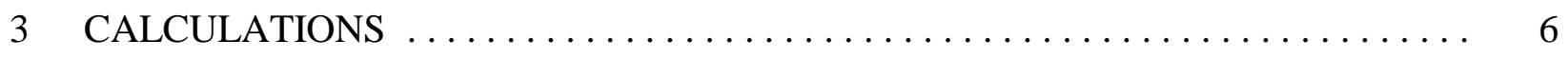

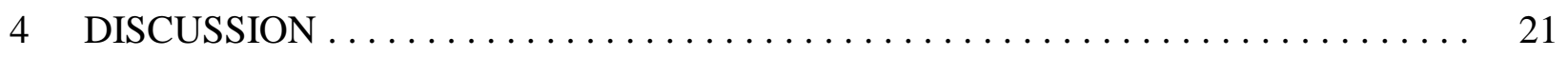

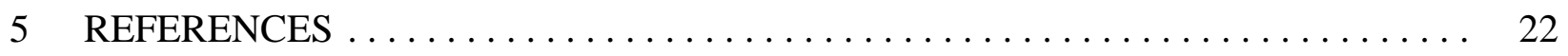

\section{FIGURES}

1 Breakthrough Curves for a Trench, Vault, and Mine for a Fairly Mobile,

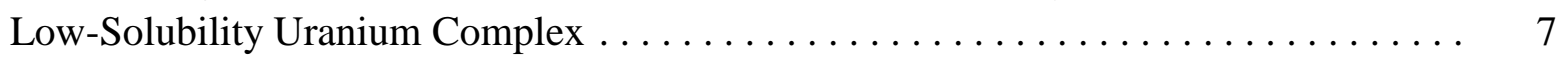

2 Breakthrough Curves for a Trench, Vault, and Mine for a Fairly Immobile,

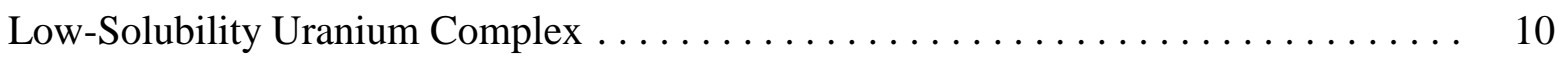

3 Breakthrough Curves for a Trench for a Fairly Mobile, Very Soluble

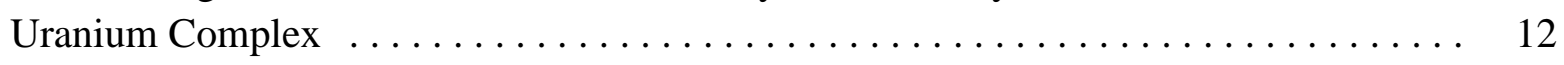

4 Breakthrough Curves for a Vault for a Fairly Mobile, Very Soluble

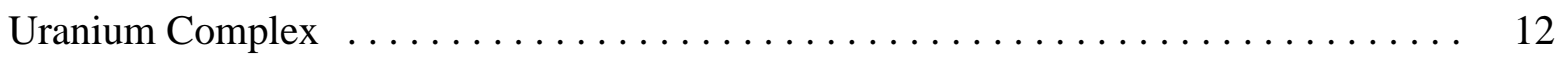

5 Breakthrough Curves for a Mine for a Fairly Mobile, Very Soluble

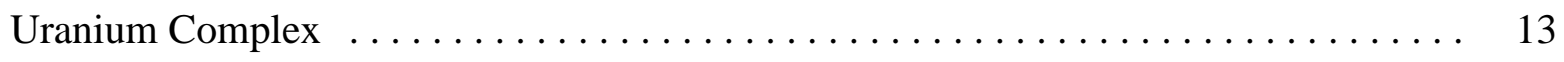

6 Breakthrough Curves for a Trench for a Fairly Immobile, Very Soluble

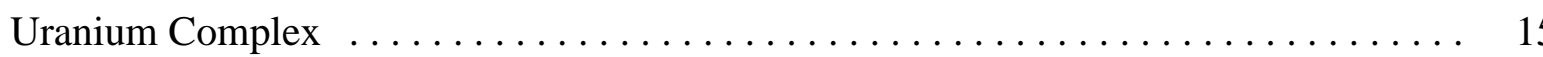

7 Breakthrough Curves for a Vault for a Fairly Immobile, Very Soluble Uranium Complex $\ldots \ldots \ldots \ldots \ldots \ldots \ldots \ldots \ldots \ldots \ldots \ldots \ldots \ldots \ldots \ldots \ldots \ldots \ldots$

8 Breakthrough Curves for a Mine for a Fairly Immobile, Very Soluble Uranium Complex $\ldots \ldots \ldots \ldots \ldots \ldots \ldots \ldots \ldots \ldots \ldots \ldots \ldots \ldots \ldots \ldots \ldots \ldots$ 


\section{TABLES}

1 Footprint Areas for the Long-Term Disposal of $\mathrm{UF}_{4} \ldots \ldots \ldots \ldots$

2 Duration Times for Contaminant Sources $\ldots \ldots \ldots \ldots \ldots \ldots \ldots \ldots \ldots \ldots \ldots$

3 Summary of Hydrological Parameters Used for the Disposal Calculations . . . . . . . 7

4 Maximum Concentrations and Occurrence Times for Long-Term Disposal of $\mathrm{UF}_{4} \ldots \ldots$

5 Summary of Concentrations at 1,000 Years at the Water Table for Long-Term

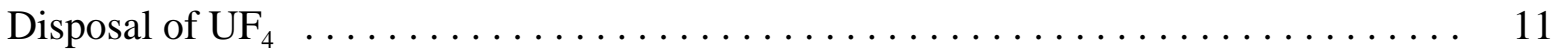

6 Lengths of Disposal Cell Footprint Parallel to the Direction of Groundwater Flow . . . 17

7 Dilution Factors for Mixing at the Water Table $\ldots \ldots \ldots \ldots \ldots \ldots \ldots \ldots \ldots$

8 Summary of Concentrations at 1,000 Years after Dilution at the Water Table ... . . 18

9 Maximum Concentrations and Occurrence Times for Long-Term Disposal

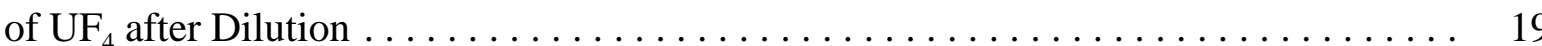




\title{
GROUNDWATER CALCULATIONS FOR DEPLETED URANIUM DISPOSED OF AS URANIUM TETRAFLUORIDE $\left(\mathrm{UF}_{4}\right)$
}

by

D. Tomasko

\begin{abstract}
This report discusses calculations performed to estimate the impacts on groundwater from the long-term disposal of depleted uranium in the form of uranium tetrafluoride $\left(\mathrm{UF}_{4}\right)$ in a trench, vault, and mined cavity. The calculations were done for a deep groundwater system, typical of conditions in the western United States. They were performed for two initial inventories of $\mathrm{UF}_{4}: 500,000$ and 630,000 metric tons. Disposal was in either 30- or 50-gal drums. All of the contaminant and radioactivity concentrations at the water table are predicted to be very low, even for a fairly mobile compound. In general, concentrations after 1,000 years at the water table would be about an order of magnitude greater for disposal in a deep mine than for disposal in a trench or vault. The largest activity concentration at the water table after 1,000 years would be derived from a failed mine that releases a fairly mobile and very soluble uranium complex; it would be about $8.6 \times 10^{-6} \mathrm{pCi} / \mathrm{L}$ for 500,000 metric tons of $\mathrm{UF}_{4}$ disposed of in 30 -gal drums. The smallest activity concentrations at the water table after 1,000 years would, in general, be derived from a failed trench $\left(1.2 \times 10^{-9} \mathrm{pCi} / \mathrm{L}\right)$, if the contaminant reached the water table as schoepite. Although all the activity concentrations at the water table after 1,000 years are predicted to be small, maximum activity concentrations could still be large, even after dilution. Maximum activity concentrations of uranium would exceed $900 \mathrm{pCi} / \mathrm{L}$ for a failed disposal facility if a very soluble and mobile uranium complex formed. If the solubility of the uranium compound was small $\left(2.4 \times 10^{-3} \mathrm{~g} / \mathrm{L}\right)$, the resulting activity concentrations would be small, less than $2.5 \mathrm{pCi} / \mathrm{L}$. The estimated time for these maximum concentrations would range from 65,000 to $2,000,000$ years.
\end{abstract}

\section{INTRODUCTION}

This report discusses calculations performed to estimate the impacts on groundwater produced from the long-term disposal of depleted uranium in the form of uranium tetrafluoride $\left(\mathrm{UF}_{4}\right)$ 
in an engineered trench, a vault, and a mined cavity. The calculations were done for a deep groundwater system, typical of conditions in the western portion of the country. Calculations were performed for two initial inventories of $\mathrm{UF}_{4}: 500,000$ and 630,000 metric tons (t). These values are consistent with 560,000 and 705,000 t of disposed uranium hexafluoride $\left(\mathrm{UF}_{6}\right)$, respectively, discussed in Folga and Kier (2001). Disposal was in either 30- or 50-gal drums. Where possible, the calculations follow the same format as those reported in the Programmatic Environmental Impact Statement for Alternative Strategies for the Long-Term Management and Use of Depleted Uranium Hexafluoride (PEIS) published by the U.S. Department of Energy (DOE 1997). 


\section{SOURCE TERM}

Solid $\mathrm{UF}_{4}$ in storage poses no direct threat to groundwater resources. However, $\mathrm{UF}_{4}$ is an unstable compound that can dissolve and react with oxygen and water to form more complex compounds. These compounds can then migrate into the groundwater system and be transported by existing hydraulic gradients.

In order to perform transport calculations for the groundwater, a source term is needed. This source term requires an estimate of the length of time that uranium is being introduced into the system and its initial concentration at the discharge point. For simplicity, the source term is assumed to behave like a unit step function (Hildebrand 1976) that has a value $C_{0}$ for a time $\Delta t$ and then returns to zero. This initial concentration, $C_{0}$, is assumed to be equal to the solubility of either $\mathrm{UF}_{4}$ or the solubility of one of the many possible uranium compound complexes. The duration of the source term, $\Delta t$, can be estimated as the dissolution time for the entire inventory of $\mathrm{UF}_{4}$ in the disposal area.

After exposure to water, $\mathrm{UF}_{4}$ dissolves and then undergoes hydrolysis. Dissolution to a solubility limit is assumed to be instantaneous. The time for hydrolysis, however, can be significant. If the hydrolysis time is long compared to the travel time to a potential receptor, the dissolved form of uranium at the receptor will be $\mathrm{UF}_{4}$. However, if the hydrolysis time is short compared to the travel time, other uranium compounds are possible.

In the presence of oxygen and water, $\mathrm{UF}_{4}$ is unstable and dissolves and chemically reacts. The reported solubility of $\mathrm{UF}_{4}$ ranges from about 0.03 to $0.1 \mathrm{~g} / \mathrm{L}$ at $25^{\circ} \mathrm{C}$, per information from Oak Ridge National Laboratory in 1960 on Atomic Energy Commission Report AECD-3412 and from Kozak et al. (1992). $\mathrm{UF}_{4}$ can also chemically react with oxygen and water to form schoepite $\left(\mathrm{UO}_{3} \cdot 2 \mathrm{H}_{2} \mathrm{O}\right)$ via the following chemical reaction:

$$
\mathrm{UF}_{4}+\frac{1}{2} \mathrm{O}_{2}(g)+4 \mathrm{H}_{2} \mathrm{O} \rightarrow 4 \mathrm{HF}(\mathrm{aq})+\mathrm{UO}_{3} \cdot 2 \mathrm{H}_{2} \mathrm{O} .
$$

In addition, the following reaction can occur, producing triuranium octaoxide $\left(\mathrm{U}_{3} \mathrm{O}_{8}\right)$ :

$$
3 \mathrm{UF}_{4}+\mathrm{O}_{2}(g)+6 \mathrm{H}_{2} \mathrm{O} \rightarrow 12 \mathrm{HF}(\mathrm{aq})+\mathrm{U}_{3} \mathrm{O}_{8} .
$$

The $\mathrm{U}_{3} \mathrm{O}_{8}$ produced in the reaction given by Equation 2 can then form schoepite under oxidizing conditions. The solubility of schoepite is approximately $2.4 \times 10^{-3} \mathrm{~g} / \mathrm{L}$ (Kozak et al. 1992).

Because of its corrosive properties, the HF released by the above reactions is assumed to react with material such as Portland cement grout and carbonate in limestone formations, releasing 
carbonates into solution. Because of such reactions, the HF is assumed to be removed from the groundwater pathway and is not considered to be a risk at the location of potential receptors.

Dissolved carbonate released by reactions involving HF can have a significant effect on the aqueous chemistry and solubility of uranium (U[VI]) through the formation of strong anionic carbonato complexes (DOE and U.S. Environmental Protection Agency [EPA] 1999). Some of these compounds include dioxouranium carbonate species: $\mathrm{UO}_{2} \mathrm{CO}_{3}, \mathrm{UO}_{2}\left(\mathrm{CO}_{3}\right)_{2}$, and $\mathrm{UO}_{2}\left(\mathrm{CO}_{3}\right)_{3}$. The predominant species formed depends on the $\mathrm{pH}$ of the system. Under neutral conditions $(\mathrm{pH}=7.0)$, the predominant form is $\mathrm{UO}_{2}\left(\mathrm{CO}_{3}\right)_{2}$. For slightly acidic conditions $(\mathrm{pH}=6.0)$, such as those expected in the presence of the released $\mathrm{HF}$, the predominant form is $\mathrm{UO}_{2} \mathrm{CO}_{3}$ (Langmuir 1978). The solubility of $\mathrm{UO}_{2} \mathrm{CO}_{3}$ is reported as $0.028 \mathrm{~g} / \mathrm{L}$ (Gmelin 1983). If nitrogen is also present in solution, additional uranium complexes can form. One of these, an ammonium carbonate uranium complex that has the chemical formula $\left(\mathrm{NH}_{4}\right)_{4}\left(\mathrm{UO}_{2}\left(\mathrm{CO}_{3}\right)_{3}\right.$, has a solubility of $23 \mathrm{~g} / \mathrm{L}$ (Gmelin 1983).

As the above discussion indicates, the final form of uranium in solution at the location of a potential receptor is a complex function of the reaction time of the dissolved phase present relative to the transport time to a potential receptor, the physical and chemical attributes of the disposal facility, and the geochemistry of the receiving water. Because the reaction rate for $\mathrm{UF}_{4}$ hydrolysis is not well known (Kozak et al. 1992), and because the geochemistry of the groundwater is sitespecific, a range of solubilities was selected to bracket the calculations. At the low end of the solubility range, the solubility is assumed to be equal to that of schoepite $\left(2.4 \times 10^{-3} \mathrm{~g} / \mathrm{L}\right)$. Because groundwater uranium concentrations produced by schoepite during long-term disposal are very small (Tomasko 1997a), a smaller solubility was not needed for the present analyses. At the high end of the solubility range, the solubility is assumed to be four orders of magnitude greater $(24 \mathrm{~g} / \mathrm{L})$. This value is similar to the solubility of the ammonium carbonate uranium complex mentioned above.

An intermediate set of calculations could also be performed for this study. Here, the solubility would be set to equal the solubility of $\mathrm{UF}_{4}$ (approximately $0.1 \mathrm{~g} / \mathrm{L}$ ). For this calculation, the hydrolysis of $\mathrm{UF}_{4}$ would be assumed to be slow when compared with the transport time to a potential receptor. For this condition, $\mathrm{UF}_{4}$ would remain in solution and not react significantly. Its initial concentration at the point of discharge to the environment would be equal to its solubility $(0.1 \mathrm{~g} / \mathrm{L})$. Because this value lies within the range selected for the analyses, a separate analysis was not performed for the intermediate solubility.

Because the disposed radioactive material is assumed to be soluble, it will act as a source of contamination for a number of years. The duration time for the source can be estimated by using the following expression:

$$
\Delta t=\frac{M_{t}}{V S_{o l}},
$$


where $A$ is the area of the disposal facility footprint, $M_{t}$ is the total initial inventory of contaminant $\left(500,000\right.$ and $630,000 \mathrm{t}$ of $\left.\mathrm{UF}_{4}\right), S_{i} l_{i}$ is the solubility of the $i^{\text {th }}$ radioactive material (i.e., $2.4 \times 10^{-3}$ or $24 \mathrm{~g} / \mathrm{L})$, and $V$ is the infiltration velocity of water.

For a dry climate, the quantity of water infiltrating a soil column is approximately $1 \%$ of the annual precipitation (Rice et al. 1989). For an average annual precipitation of $10 \mathrm{in}$. in an arid climate (Tomasko 1997a), the net rate of water infiltration is $0.1 \mathrm{in} . / \mathrm{yr}\left(2.54 \times 10^{-3} \mathrm{~m} / \mathrm{yr}\right)$. The range of the solubilities of the potential radioactive dissolution products for Equation 3 is $2.4 \times 10^{-3}$ to $24 \mathrm{~g} / \mathrm{L}$, as discussed above. Footprint areas for the different disposal options are listed in Table 1 (Folga and Kier 2001).

A list of duration times for the various sources of contamination estimated with Equation 3 are given in Table 2 for disposal in a trench, vault, and deep mine. Except for the highly soluble uranium complex, all source durations are very long, exceeding 33 million years. The shortest source duration is 3,320 years for disposing of 500,000 t of $\mathrm{UF}_{4}$ in 30-gal drums in a mine in which water reacts with the radioactive material to form a very soluble $(24 \mathrm{~g} / \mathrm{L})$ uranium complex.

TABLE 1 Footprint Areas (in hectares) for the Long-Term Disposal of UF $_{4}$

\begin{tabular}{lccccc}
\hline & \multicolumn{2}{c}{$500,000 \mathrm{t}$} & & \multicolumn{2}{c}{$630,000 \mathrm{t}$} \\
\cline { 2 - 3 } \cline { 5 - 6 } Disposal Method & 30-gal Drums & 50 -gal Drums & & 30-gal Drums & 50 -gal Drums \\
\hline & & & & 25.5 & 21.6 \\
Trench & 20.6 & 17.4 & & 25.6 & 37.9 \\
Vault & 25.4 & 31.6 & & 31.6 & 234 \\
Mine & 247 & 187 & 310 & \\
\hline
\end{tabular}

TABLE 2 Duration Times (in years) for Contaminant Sources

\begin{tabular}{rlrrrrr}
\hline & & \multicolumn{2}{c}{$500,000 \mathrm{t}$} & & \multicolumn{2}{c}{$630,000 \mathrm{t}$} \\
\cline { 3 - 4 } \cline { 6 - 7 } Facility & \multicolumn{1}{c}{$\begin{array}{c}\text { Solubility } \\
(\mathrm{g} / \mathrm{L})\end{array}$} & 30 -gal Drums & 50 -gal Drums & & 30 -gal Drums & 50 -gal Drums \\
\hline \multirow{3}{*}{ Trench } & $2.4 \times 10^{-3}$ & $398,000,000$ & $471,000,000$ & & $501,000,000$ & $593,000,000$ \\
& 24 & 39,800 & 47,100 & 50,100 & 59,300 \\
Vault & $2.4 \times 10^{-3}$ & $323,000,000$ & $260,000,000$ & & $407,000,000$ & $328,000,000$ \\
& 24 & 32,300 & 26,000 & & 40,700 & 32,800 \\
Mine & $2.4 \times 10^{-3}$ & $33,200,000$ & $43,800,000$ & & $41,200,000$ & $54,700,000$ \\
& 24 & 3,320 & 4,380 & & 4,120 & 5,470 \\
\hline
\end{tabular}




\section{CAlCulations}

A one-dimensional analytical solution of the advection/dispersion equation was used to calculate the concentrations of the various radioactive contaminants (Tomasko 1997b). The calculations were performed for a time of 1,000 years, to be consistent with calculations done for the PEIS (DOE 1997), and for groundwater directly beneath the footprint of the disposal facility. Longitudinal transport was not included because the times required for transport to a point 1,000 ft from the disposal facility are much shorter (about 50 to 500 years for a groundwater velocity of $110 \mathrm{ft} / \mathrm{yr}$ and for transport velocities that are 5 to 50 times slower, respectively, than the velocity of the groundwater [retardations of 5 and 50]) than the times required for transport through the unsaturated zone (60,000 to 300,000 years for a deep mine with a thickness of $100 \mathrm{ft}$ and for a trench/vault with a thickness of $500 \mathrm{ft}$, respectively, and a retardation of 5 . Because of this shorter travel time, concentrations at a distance of $1,000 \mathrm{ft}$ from the facility would be essentially the same as those calculated for a point directly below the facility footprint. In addition to groundwater calculations performed at 1,000 years, the calculations were extended to determine the maximum concentration that would be achieved and the time of this maximum value.

Longitudinal dispersion was calculated by using the following expression (Bear 1972):

$$
D=\alpha V,
$$

where $\alpha$ is the dispersivity of the formation and $V$ is the infiltration velocity of the water $(0.1 \mathrm{in} . / \mathrm{yr})$. Dispersivity was assumed to be scale-dependent (Lallamand-Barres and Peaudecerf 1978), i.e.,

$$
\alpha=0.1 L,
$$

where $L$ is the separation distance between the source release point and the point of interest (the water table directly below the disposal facility footprint). For the trench/vault, longitudinal dispersion was $0.4 \mathrm{ft}^{2} / \mathrm{yr}$; for the mine, the dispersion was $0.083 \mathrm{ft}^{2} / \mathrm{yr}$. A summary of parameters for the disposal calculations is given in Table 3.

As a contaminant is transported by groundwater, it may have an apparent velocity that is less than the velocity of the water because of sorption. This process is known as retardation (Freeze and Cherry 1979). Because retardation of a dissolved radionuclide is a site-specific parameter that has a high degree of uncertainty, two values were used to bound the calculations, 5 and 50 . These values represent a fairly mobile contaminant (retardation of 5) and a contaminant that undergoes substantial sorption along its flow path (retardation of 50).

Figure 1 shows breakthrough curves of the dimensionless concentration (concentration at a time $t$ divided by the initial concentration of the contaminant, i.e., $C / C_{0}$ ) for schoepite at the water 
TABLE 3 Summary of Hydrological Parameters Used for the Disposal Calculations

\begin{tabular}{llll}
\hline \multicolumn{1}{c}{ Parameter } & \multicolumn{1}{c}{ Trench } & \multicolumn{1}{c}{ Vault } & \multicolumn{1}{c}{ Mine } \\
\hline & & & \\
Depth to water table (ft) & 500 & 500 & 100 \\
Infiltration velocity of water (ft/yr) & $8.33 \times 10^{-3}$ & $8.33 \times 10^{-3}$ & $8.33 \times 10^{-3}$ \\
Saturated zone water velocity (ft/yr) & 110 & 110 & 110 \\
Longitudinal dispersion in unsaturated zone $\left(\mathrm{ft}^{2} / \mathrm{yr}\right)$ & 0.4 & 0.4 & 0.083 \\
Longitudinal dispersion in saturated zone $\left(\mathrm{ft}^{2} / \mathrm{yr}\right)$ & 11,000 & 11,000 & 11,000 \\
Retardation & 5 and 50 & 5 and 50 & 5 and 50 \\
Thickness of saturated zone (ft) & 100 & 100 & 100 \\
Porosity & 0.1 & 0.1 & 0.1 \\
Hydraulic conductivity of saturated zone $(\mathrm{ft} / \mathrm{yr})$ & 11,000 & 11,000 & 11,000 \\
Hydraulic gradient in saturated zone & 0.001 & 0.001 & 0.001 \\
\hline
\end{tabular}

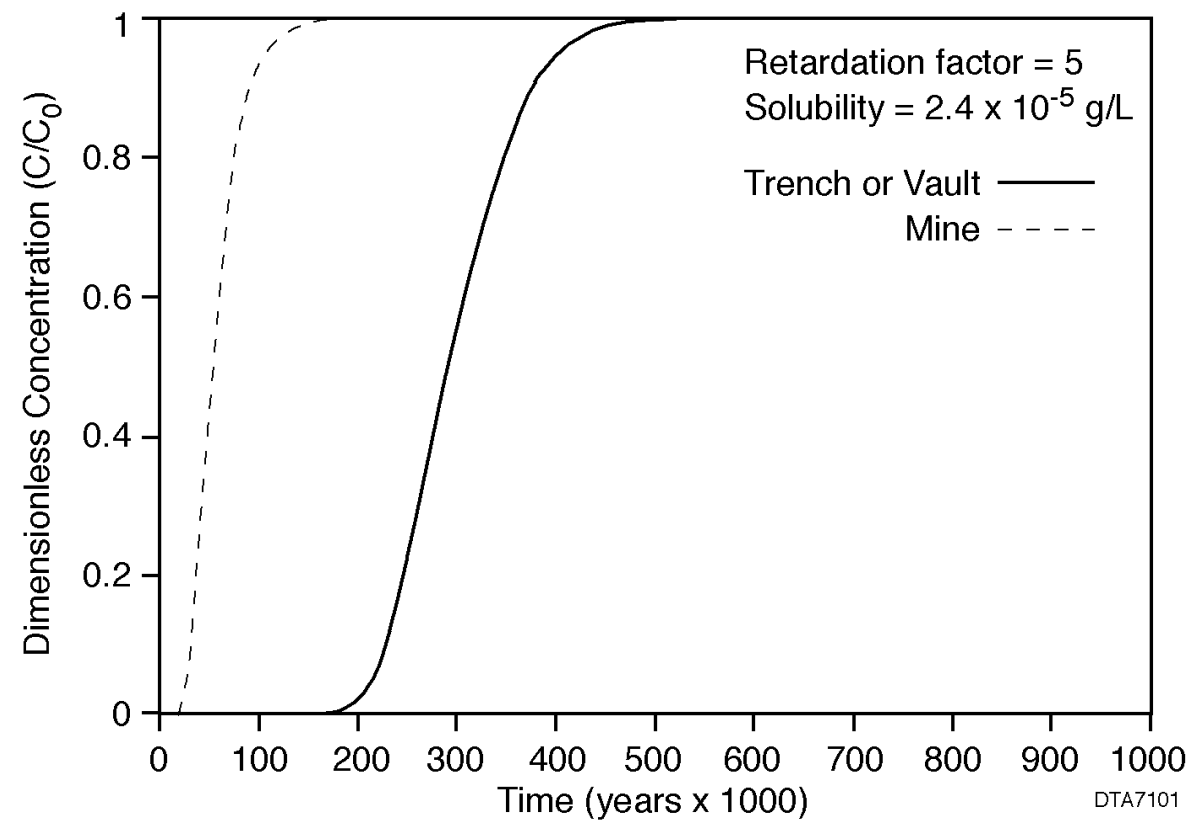

FIGURE 1 Breakthrough Curves for a Trench, Vault, and Mine for a Fairly Mobile, Low-Solubility Uranium Complex 
table as a function of time for disposal in a vault or trench and in a mine for fairly mobile conditions (retardation of 5). For the time scale shown, there are no differences between the breakthrough curves for disposal in 30- or 50-gal drums. Because of the long durations of the source possible with schoepite (Table 3 ), the maximum concentration at the water table can equal the initial concentration (i.e., $C / C_{0}=1.0$ ). In a trench or vault, the maximum concentration would be reached after about 550,000 years (Table 4). In a mine, the maximum concentration would be reached after about 200,000 years. Maximum concentrations for a mine occur earlier because of the shorter travel distance from the mine to the water table (100 versus $500 \mathrm{ft}$ ). For more sorption (retardation of 50), the peak concentration $\left(C / C_{0}=1\right)$ for a trench or vault would be reached after approximately 5 million years (Table 4) as shown in Figure 2. For a mine, this concentration would be reached after about 2 million years.

The dimensionless concentrations for schoepite released from a trench or vault after 1,000 years are $2.1 \times 10^{-9}$ and $6.1 \times 10^{-21}$ for retardations of 5 and 50, respectively (Table 5). For a mine, the dimensionless concentrations after 1,000 years would be $3.9 \times 10^{-9}$ and $1.7 \times 10^{-9}$ for retardations of 5 and 50, respectively. As shown in Table 4, for a specific activity of $2.4 \times 10^{-7} \mathrm{Ci} / \mathrm{g}$ (Tomasko 1997a), the maximum uranium activity concentration from a failed trench, vault, or mine would be $576 \mathrm{pCi} / \mathrm{L}\left(1 \mathrm{pCi}\right.$ or picocurie $=1 \times 10^{-12} \mathrm{Ci}$ or curies $)$.

By multiplying the dimensionless concentrations shown in Figures 1 and 2 by the initial concentration of the source $\left(2.4 \times 10^{-3} \mathrm{~g} / \mathrm{L}\right)$, the uranium concentrations after 1,000 years for a failed trench or vault would be $5.0 \times 10^{-12}$ and $1.5 \times 10^{-23} \mathrm{~g} / \mathrm{L}$ for retardations of 5 and 50 , respectively (Table 5). For a failed mine, the uranium concentrations would be $9.5 \times 10^{-12}$ and $4.0 \times 10^{-12}$ for retardations of 5 and 50 , respectively.

By multiplying the uranium concentration in $\mathrm{g} / \mathrm{L}$ by the specific activity of the compound (Ci/g), the uranium activity concentration for the compound can be found. For a specific activity of $2.4 \times 10^{-7} \mathrm{Ci} / \mathrm{g}$ for schoepite (Tomasko 1997a), the uranium activity concentrations from a failed trench or vault at 1,000 years would be $1.2 \times 10^{-6}$ and $3.6 \times 10^{-18} \mathrm{pCi} / \mathrm{L}$, for retardations of 5 and 50 , respectively. For a failed mine, the activity concentration of the uranium would be $2.3 \times 10^{-6}$ and $9.6 \times 10^{-7} \mathrm{pCi} / \mathrm{L}$ for retardations of 5 and 50 , respectively.

If the solubility of the uranium were increased by four orders of magnitude to $24 \mathrm{~g} / \mathrm{L}$, the duration time of the source from a failed disposal facility would be decreased by a factor of 10,000 (Table 2). Figures 3 through 5 show the breakthrough curves for a highly soluble uranium complex from a trench, vault, and mine, respectively. For the higher solubility cases, the maximum dimensionless concentration $\left(C / C_{0}\right)$ reached is less than 1.0, and the maximum occurs much earlier in time (Table 4). A maximum dimensionless uranium concentration of 0.39 occurs for a failed trench in which 630,000 t of $\mathrm{UF}_{4}$ are disposed of in 50-gal drums. This maximum would occur after about 315,000 years for an assumed retardation of 5. For an initial source term concentration of $24 \mathrm{~g} / \mathrm{L}$, the maximum concentration would be $9.4 \mathrm{~g} / \mathrm{L}$. The smallest dimensionless maximum 
TABLE 4 Maximum Concentrations and Occurrence Times for Long-Term Disposal of UF

\begin{tabular}{|c|c|c|c|c|c|c|c|c|}
\hline \multirow[b]{2}{*}{$\begin{array}{c}\text { Solubility } \\
(\mathrm{g} / \mathrm{L})\end{array}$} & \multirow[b]{2}{*}{$\mathrm{R}^{\mathrm{a}}$} & \multirow[b]{2}{*}{ Facility } & \multicolumn{3}{|c|}{$500,000 \mathrm{t}$ in 30 -gal Drums } & \multicolumn{3}{|c|}{$500,000 \mathrm{t}$ in 50 -gal Drums } \\
\hline & & & $C / C_{0}$ & $\begin{array}{c}\text { Concentration } \\
(\mathrm{g} / \mathrm{L})^{b}\end{array}$ & $\begin{array}{c}\text { Activity } \\
\text { Concentration } \\
(\mathrm{pCi} / \mathrm{L})^{\mathrm{c}}\end{array}$ & $C / C_{0}$ & $\begin{array}{c}\text { Concentration } \\
(\mathrm{g} / \mathrm{L}){ }^{b}\end{array}$ & $\begin{array}{c}\text { Activity } \\
\text { Concentration } \\
(\mathrm{pCi} / \mathrm{L})^{\mathrm{c}}\end{array}$ \\
\hline $2.4 \times 10^{-3}$ & 5 & Trench & $\begin{array}{l}1.0 \\
550,000 \mathrm{yr}\end{array}$ & $2.4 \times 10^{-3}$ & 576 & $\begin{array}{l}1.0 \\
550,000 \mathrm{yr}\end{array}$ & $2.4 \times 10^{-3}$ & 576 \\
\hline \multirow{11}{*}{24} & \multirow{5}{*}{50} & Vault & $\begin{array}{l}1.0 \\
550,000 \mathrm{yr}\end{array}$ & $2.4 \times 10^{-3}$ & 576 & $\begin{array}{l}1.0 \\
550,000 \mathrm{yr}\end{array}$ & $2.4 \times 10^{-3}$ & 576 \\
\hline & & Mine & $\begin{array}{l}1.0 \\
200,000 \mathrm{yr}\end{array}$ & $2.4 \times 10^{-3}$ & 576 & $\begin{array}{l}1.0 \\
200,000 \mathrm{yr}\end{array}$ & $2.4 \times 10^{-3}$ & 576 \\
\hline & & Trench & $\begin{array}{l}1.0 \\
5,000,000 \mathrm{yr}\end{array}$ & $2.4 \times 10^{-3}$ & 576 & $\begin{array}{l}1.0 \\
5,000,000 \mathrm{yr}\end{array}$ & $2.4 \times 10^{-3}$ & 576 \\
\hline & & Vault & $\begin{array}{l}1.0 \\
5,000,000 \mathrm{yr}\end{array}$ & $2.4 \times 10^{-3}$ & 576 & $\begin{array}{l}1.0 \\
5,000,000 \mathrm{yr}\end{array}$ & $2.4 \times 10^{-3}$ & 576 \\
\hline & & Mine & $\begin{array}{l}1.0 \\
2,000,000 \mathrm{yr}\end{array}$ & $2.4 \times 10^{-3}$ & 576 & $\begin{array}{l}1.0 \\
2,000,000 \mathrm{yr}\end{array}$ & $2.4 \times 10^{-3}$ & 576 \\
\hline & 5 & Trench & $\begin{array}{l}0.27 \\
310,000 \mathrm{yr}\end{array}$ & 6.5 & $1.0 \times 10^{6}$ & $\begin{array}{l}0.32 \\
315,000 \mathrm{yr}\end{array}$ & 7.7 & $1.2 \times 10^{6}$ \\
\hline & \multirow{5}{*}{50} & Vault & $\begin{array}{l}0.22 \\
305,000 \mathrm{yr}\end{array}$ & 5.3 & $5.3 \times 10^{5}$ & $\begin{array}{l}0.18 \\
300,000 \mathrm{yr}\end{array}$ & 4.3 & $6.9 \times 10^{5}$ \\
\hline & & Mine & $\begin{array}{l}0.06 \\
60,000 \mathrm{yr}\end{array}$ & 1.4 & $2.2 \times 10^{5}$ & $\begin{array}{l}0.08 \\
65,000 \mathrm{yr}\end{array}$ & 1.9 & $1.6 \times 10^{5}$ \\
\hline & & Trench & $\begin{array}{l}0.043 \\
2,900,000 \mathrm{yr}\end{array}$ & 1.0 & $1.6 \times 10^{5}$ & $\begin{array}{l}0.036 \\
2,850,000 \mathrm{yr}\end{array}$ & 0.9 & $1.4 \times 10^{5}$ \\
\hline & & Vault & $\begin{array}{l}0.022 \\
2,850,000 \mathrm{yr}\end{array}$ & 0.5 & $8.0 \times 10^{4}$ & $\begin{array}{l}0.017 \\
2,800,000 \mathrm{yr}\end{array}$ & 0.4 & $6.4 \times 10^{4}$ \\
\hline & & Mine & $\begin{array}{l}0.006 \\
4 \underline{50}, 000 \mathrm{yr}\end{array}$ & 0.14 & $2.2 \times 10^{4}$ & $\begin{array}{l}0.0082 \\
445,000 \mathrm{yr}\end{array}$ & 0.2 & $3.2 \times 10^{4}$ \\
\hline \multirow[b]{2}{*}{$\begin{array}{l}\text { Solubility } \\
(\mathrm{g} / \mathrm{L})\end{array}$} & \multirow[b]{2}{*}{$\mathrm{R}^{\mathrm{a}}$} & \multirow[b]{2}{*}{ Facility } & \multicolumn{3}{|c|}{$630,000 \mathrm{t}$ in 30 -gal drums } & \multicolumn{3}{|c|}{$630,000 \mathrm{t}$ in 50 -gal drums } \\
\hline & & & $C / C_{0}$ & $\begin{array}{c}\text { Concentration } \\
(\mathrm{g} / \mathrm{L})\end{array}$ & $\begin{array}{c}\text { Activity } \\
\text { Concentration } \\
(\mathrm{pCi} / \mathrm{L})^{\mathrm{c}}\end{array}$ & $C / C_{0}$ & $\begin{array}{c}\text { Concentration } \\
(\mathrm{g} / \mathrm{L})^{\mathrm{b}}\end{array}$ & $\begin{array}{c}\text { Activity } \\
\text { Concentration } \\
(\mathrm{pCi} / \mathrm{L})^{\mathrm{c}}\end{array}$ \\
\hline \multirow[t]{6}{*}{$2.4 \times 10^{-3}$} & 5 & Trench & $\begin{array}{l}1.0 \\
550,000 \mathrm{yr}\end{array}$ & $2.4 \times 10^{-3}$ & 576 & $\begin{array}{l}1.0 \\
550,000 \mathrm{yr}\end{array}$ & $2.4 \times 10^{-3}$ & 576 \\
\hline & & Vault & $\begin{array}{l}1.0 \\
550,000 \mathrm{yr}\end{array}$ & $2.4 \times 10^{-3}$ & 576 & $\begin{array}{l}1.0 \\
550,000 \mathrm{y}\end{array}$ & $2.4 \times 10^{-3}$ & 576 \\
\hline & & Mine & $\begin{array}{l}1.0 \\
200,000 \mathrm{yr}\end{array}$ & $2.4 \times 10^{-3}$ & 576 & $\begin{array}{l}1.0 \\
200,000 \mathrm{yr}\end{array}$ & $2.4 \times 10^{-3}$ & 576 \\
\hline & 50 & Trench & $\begin{array}{l}1.0 \\
5,000,000 \mathrm{yr}\end{array}$ & $2.4 \times 10^{-3}$ & 576 & $\begin{array}{l}1.0 \\
5,000,000 \mathrm{yr}\end{array}$ & $2.4 \times 10^{-3}$ & 576 \\
\hline & & Vault & $\begin{array}{l}1.0 \\
5,000,000 \mathrm{yr}\end{array}$ & $2.4 \times 10^{-3}$ & 576 & $\begin{array}{l}1.0 \\
5,000,000 \mathrm{yr}\end{array}$ & $2.4 \times 10^{-3}$ & 576 \\
\hline & & Mine & $\begin{array}{l}1.0 \\
2,000,000 \mathrm{yr}\end{array}$ & $2.4 \times 10^{-3}$ & 576 & $\begin{array}{l}1.0 \\
2,000,000 \mathrm{yr}\end{array}$ & $2.4 \times 10^{-3}$ & 576 \\
\hline
\end{tabular}


TABLE 4 (Cont.)

\begin{tabular}{|c|c|c|c|c|c|c|c|c|}
\hline \multirow[b]{2}{*}{$\begin{array}{l}\text { Solubility } \\
(\mathrm{g} / \mathrm{L})\end{array}$} & \multirow[b]{2}{*}{$\mathrm{R}^{\mathrm{a}}$} & \multirow[b]{2}{*}{ Facility } & \multicolumn{3}{|c|}{$630,000 \mathrm{t}$ in 30 -gal drums } & \multicolumn{3}{|c|}{$630,000 \mathrm{t}$ in 50 -gal drums } \\
\hline & & & $C / C_{0}$ & $\begin{array}{c}\text { Concentration } \\
(\mathrm{g} / \mathrm{L})^{b}\end{array}$ & $\begin{array}{c}\text { Activity } \\
\text { Concentration } \\
(\mathrm{pCi} / \mathrm{L})^{\mathrm{c}}\end{array}$ & $C / C_{0}$ & $\begin{array}{c}\text { Concentration } \\
(\mathrm{g} / \mathrm{L})\end{array}$ & $\begin{array}{c}\text { Activity } \\
\text { Concentration } \\
(\mathrm{pCi} / \mathrm{L})^{\mathrm{c}}\end{array}$ \\
\hline \multirow[t]{6}{*}{24} & 5 & Trench & $\begin{array}{l}0.34 \\
310,000 \mathrm{yr}\end{array}$ & 8.2 & $1.3 \times 10^{6}$ & $\begin{array}{l}0.39 \\
315,000 \mathrm{yr}\end{array}$ & 9.4 & $1.5 \times 10^{6}$ \\
\hline & & Vault & $\begin{array}{l}0.28 \\
310,000 \mathrm{yr}\end{array}$ & 6.7 & $1.1 \times 10^{6}$ & $\begin{array}{l}0.23 \\
308,000 \mathrm{yr}\end{array}$ & 5.5 & $8.8 \times 10^{5}$ \\
\hline & & Mine & $\begin{array}{l}0.075 \\
65,000 \mathrm{yr}\end{array}$ & 1.8 & $2.9 \times 10^{5}$ & $\begin{array}{l}0.1 \\
75,000 \mathrm{yr}\end{array}$ & 2.4 & $3.8 \times 10^{5}$ \\
\hline & 50 & Trench & $\begin{array}{l}0.033 \\
2,800,000 \mathrm{yr}\end{array}$ & 0.8 & $1.3 \times 10^{5}$ & $\begin{array}{l}0.028 \\
2,700,000 \mathrm{yr}\end{array}$ & 0.7 & $1.1 \times 10^{5}$ \\
\hline & & Vault & $\begin{array}{l}0.028 \\
2,900,000 \mathrm{yr}\end{array}$ & 0.7 & $1.1 \times 10^{5}$ & $\begin{array}{l}0.0225 \\
2,870,000 \mathrm{yr}\end{array}$ & 0.5 & $8.0 \times 10^{4}$ \\
\hline & & Mine & $\begin{array}{l}0.0075 \\
452,000 \mathrm{yr}\end{array}$ & 0.2 & $3.2 \times 10^{4}$ & $\begin{array}{l}0.01 \\
452,000 \mathrm{yr}\end{array}$ & 0.2 & $3.2 \times 10^{4}$ \\
\hline
\end{tabular}

\footnotetext{
${ }^{\mathrm{a}} \mathrm{R}=$ retardation factor.

${ }^{\mathrm{b}}$ Concentration is found by multiplying the dimensionless concentration, $C / C_{0}$, by the compound's solubility.

c Activity concentration is found by multiplying the concentration of a compound by its specific activity.
}

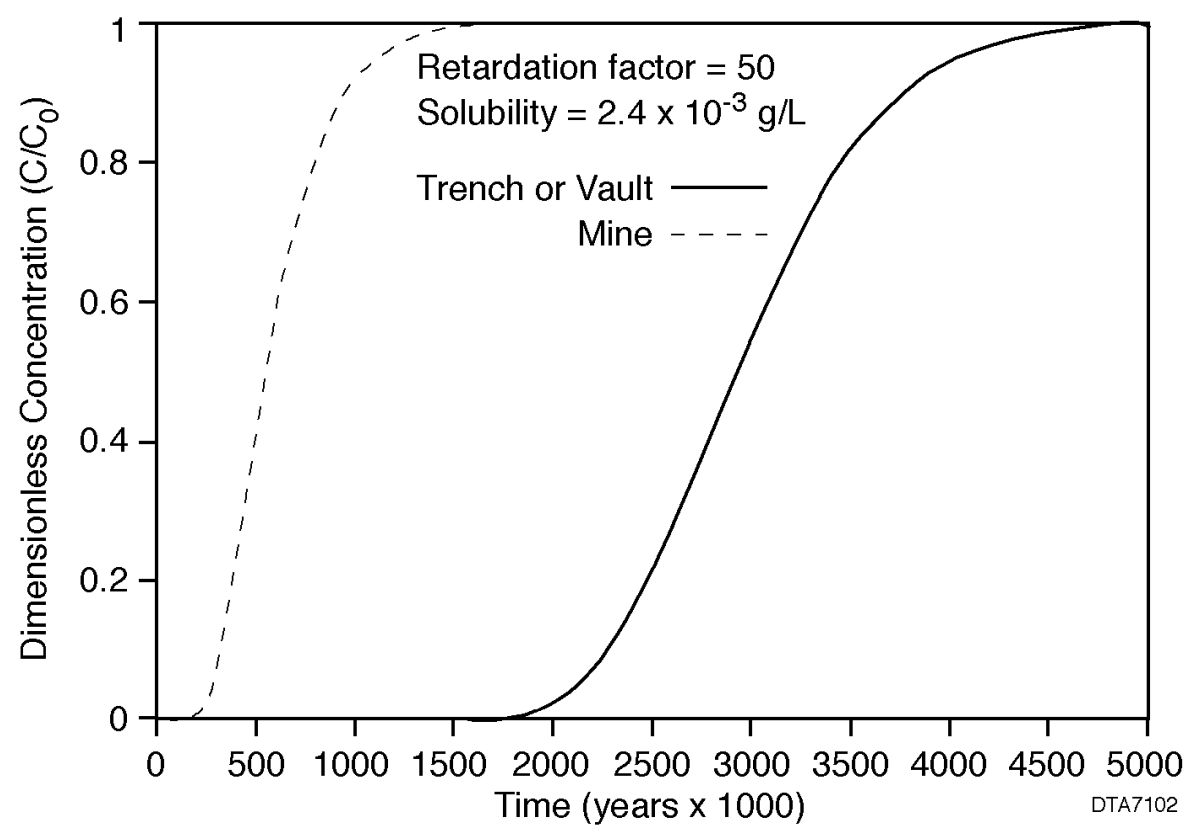

FIGURE 2 Breakthrough Curves for a Trench, Vault, and Mine for a Fairly Immobile, Low-Solubility Uranium Complex 
TABLE 5 Summary of Concentrations at 1,000 Years at the Water Table for Long-Term Disposal of $\mathrm{UF}_{4}$

\begin{tabular}{|c|c|c|c|c|c|c|c|}
\hline \multirow[b]{2}{*}{$\begin{array}{c}\text { Solubility } \\
(\mathrm{g} / \mathrm{L})\end{array}$} & \multirow[b]{2}{*}{ Facility } & \multicolumn{3}{|c|}{$500,000 \mathrm{t}$ in 30 -gal Drums } & \multicolumn{3}{|c|}{$500,000 \mathrm{t}$ in 50-gal Drums } \\
\hline & & $C / C_{0}$ & $\begin{array}{c}\text { Concentration } \\
(\mathrm{g} / \mathrm{L})\end{array}$ & $\begin{array}{c}\text { Activity } \\
\text { Concentration } \\
(\mathrm{pCi} / \mathrm{L})\end{array}$ & $C / C_{0}$ & $\begin{array}{c}\text { Concentration } \\
(\mathrm{g} / \mathrm{L})\end{array}$ & $\begin{array}{c}\text { Activity } \\
\text { Concentration } \\
(\mathrm{pCi} / \mathrm{L})\end{array}$ \\
\hline \multirow[t]{3}{*}{$2.4 \times 10^{-3}$} & Trench & $\begin{array}{l}2.1 \times 10^{-9} \\
6.1 \times 10^{-21}\end{array}$ & $\begin{array}{l}5.0 \times 10^{-12} \\
1.5 \times 10^{-23}\end{array}$ & $\begin{array}{l}1.2 \times 10^{-6} \\
3.6 \times 10^{-18}\end{array}$ & $\begin{array}{l}2.1 \times 10^{-9} \\
6.1 \times 10^{-21}\end{array}$ & $\begin{array}{l}5.0 \times 10^{-12} \\
1.5 \times 10^{-23}\end{array}$ & $\begin{array}{l}1.2 \times 10^{-6} \\
3.6 \times 10^{-18}\end{array}$ \\
\hline & Vault & $\begin{array}{l}2.1 \times 10^{-9} \\
6.1 \times 10^{-21}\end{array}$ & $\begin{array}{l}5.0 \times 10^{-12} \\
1.5 \times 10^{-23}\end{array}$ & $\begin{array}{l}1.2 \times 10^{-6} \\
3.6 \times 10^{-18}\end{array}$ & $\begin{array}{l}2.1 \times 10^{-9} \\
6.1 \times 10^{-21}\end{array}$ & $\begin{array}{l}5.0 \times 10^{-12} \\
1.5 \times 10^{-23}\end{array}$ & $\begin{array}{l}1.2 \times 10^{-6} \\
3.6 \times 10^{-18}\end{array}$ \\
\hline & Mine & $\begin{array}{l}3.9 \times 10^{-9} \\
1.7 \times 10^{-9}\end{array}$ & $\begin{array}{l}9.5 \times 10^{-12} \\
4.0 \times 10^{-12}\end{array}$ & $\begin{array}{l}2.3 \times 10^{-6} \\
9.6 \times 10^{-7}\end{array}$ & $\begin{array}{l}3.9 \times 10^{-9} \\
1.7 \times 10^{-9}\end{array}$ & $\begin{array}{l}9.5 \times 10^{-12} \\
4.0 \times 10^{-12}\end{array}$ & $\begin{array}{l}2.3 \times 10^{-6} \\
9.6 \times 10^{-7}\end{array}$ \\
\hline \multirow[t]{3}{*}{24} & Trench & $\begin{array}{l}1.9 \times 10^{-11} \\
3.4 \times 10^{-21}\end{array}$ & $\begin{array}{l}4.5 \times 10^{-10} \\
8.1 \times 10^{-20}\end{array}$ & $\begin{array}{l}7.2 \times 10^{-5} \\
1.3 \times 10^{-14}\end{array}$ & $\begin{array}{l}1.9 \times 10^{-11} \\
3.6 \times 10^{-21}\end{array}$ & $\begin{array}{l}4.6 \times 10^{-10} \\
8.7 \times 10^{-20}\end{array}$ & $\begin{array}{l}7.3 \times 10^{-5} \\
1.4 \times 10^{-14}\end{array}$ \\
\hline & Vault & $\begin{array}{l}2.2 \times 10^{-11} \\
3.0 \times 10^{-21}\end{array}$ & $\begin{array}{l}5.3 \times 10^{-10} \\
7.2 \times 10^{-20}\end{array}$ & $\begin{array}{l}8.5 \times 10^{-5} \\
1.2 \times 10^{-14}\end{array}$ & $\begin{array}{l}1.1 \times 10^{-11} \\
2.7 \times 10^{-21}\end{array}$ & $\begin{array}{l}2.5 \times 10^{-10} \\
6.4 \times 10^{-20}\end{array}$ & $\begin{array}{l}4.0 \times 10^{-5} \\
1.0 \times 10^{-14}\end{array}$ \\
\hline & Mine & $\begin{array}{l}5.6 \times 10^{-10} \\
5.5 \times 10^{-12}\end{array}$ & $\begin{array}{l}1.4 \times 10^{-8} \\
1.3 \times 10^{-10}\end{array}$ & $\begin{array}{l}2.2 \times 10^{-3} \\
2.1 \times 10^{-5}\end{array}$ & $\begin{array}{l}5.8 \times 10^{-10} \\
7.3 \times 10^{-12}\end{array}$ & $\begin{array}{l}1.4 \times 10^{-8} \\
1.8 \times 10^{-10}\end{array}$ & $\begin{array}{l}2.2 \times 10^{-3} \\
2.8 \times 10^{-5}\end{array}$ \\
\hline \multirow[b]{2}{*}{$\begin{array}{c}\text { Solubility } \\
(\mathrm{g} / \mathrm{L})\end{array}$} & & \multicolumn{3}{|c|}{$630,000 \mathrm{t}$ in 30-gal Drums } & \multicolumn{3}{|c|}{$630,000 \mathrm{t}$ in 50-gal Drums } \\
\hline & Facility & $C / C_{0}$ & $\begin{array}{c}\text { Concentration } \\
(\mathrm{g} / \mathrm{L})\end{array}$ & $\begin{array}{c}\text { Activity } \\
\text { Concentration } \\
(\mathrm{pCi} / \mathrm{L})\end{array}$ & $C / C_{0}$ & Concentration & $\begin{array}{c}\text { Activity } \\
\text { Concentration }\end{array}$ \\
\hline \multirow[t]{3}{*}{$2.4 \times 10^{-3}$} & Trench & $\begin{array}{l}2.1 \times 10^{-9} \\
6.1 \times 10^{-21}\end{array}$ & $\begin{array}{l}5.0 \times 10^{-12} \\
1.5 \times 10^{-23}\end{array}$ & $\begin{array}{l}1.2 \times 10^{-6} \\
3.6 \times 10^{-18}\end{array}$ & $\begin{array}{l}2.1 \times 10^{-9} \\
6.1 \times 10^{-21}\end{array}$ & $\begin{array}{l}5.0 \times 10^{-12} \\
1.5 \times 10^{-23}\end{array}$ & $\begin{array}{l}1.2 \times 10^{-6} \\
3.6 \times 10^{-18}\end{array}$ \\
\hline & Vault & $\begin{array}{l}2.1 \times 10^{-9} \\
6.1 \times 10^{-21}\end{array}$ & $\begin{array}{l}5.0 \times 10^{-12} \\
1.5 \times 10^{-23}\end{array}$ & $\begin{array}{l}1.2 \times 10^{-6} \\
3.6 \times 10^{-18}\end{array}$ & $\begin{array}{l}2.1 \times 10^{-9} \\
6.1 \times 10^{-21}\end{array}$ & $\begin{array}{l}5.0 \times 10^{-12} \\
1.5 \times 10^{-23}\end{array}$ & $\begin{array}{l}1.2 \times 10^{-6} \\
3.6 \times 10^{-18}\end{array}$ \\
\hline & Mine & $\begin{array}{l}3.9 \times 10^{-9} \\
1.7 \times 10^{-9}\end{array}$ & $\begin{array}{l}9.5 \times 10^{-12} \\
4.0 \times 10^{-12}\end{array}$ & $\begin{array}{l}2.3 \times 10^{-6} \\
9.6 \times 10^{-7}\end{array}$ & $\begin{array}{l}3.9 \times 10^{-9} \\
1.7 \times 10^{-9}\end{array}$ & $\begin{array}{l}9.5 \times 10^{-12} \\
4.0 \times 10^{-12}\end{array}$ & $\begin{array}{l}2.3 \times 10^{-6} \\
9.6 \times 10^{-7}\end{array}$ \\
\hline \multirow[t]{3}{*}{24} & Trench & $\begin{array}{l}1.8 \times 10^{-11} \\
3.8 \times 10^{-21}\end{array}$ & $\begin{array}{l}4.4 \times 10^{-10} \\
9.0 \times 10^{-20}\end{array}$ & $\begin{array}{l}7.1 \times 10^{-5} \\
1.4 \times 10^{-14}\end{array}$ & $\begin{array}{l}2.4 \times 10^{-11} \\
4.0 \times 10^{-21}\end{array}$ & $\begin{array}{l}5.6 \times 10^{-10} \\
9.7 \times 10^{-20}\end{array}$ & $\begin{array}{l}9.0 \times 10^{-5} \\
1.6 \times 10^{-14}\end{array}$ \\
\hline & Vault & $\begin{array}{l}2.0 \times 10^{-11} \\
3.4 \times 10^{-21}\end{array}$ & $\begin{array}{l}4.7 \times 10^{-10} \\
8.2 \times 10^{-20}\end{array}$ & $\begin{array}{l}7.6 \times 10^{-5} \\
1.3 \times 10^{-14}\end{array}$ & $\begin{array}{l}2.0 \times 10^{-11} \\
3.0 \times 10^{-21}\end{array}$ & $\begin{array}{l}4.8 \times 10^{-10} \\
7.3 \times 10^{-20}\end{array}$ & $\begin{array}{l}7.6 \times 10^{-5} \\
1.2 \times 10^{-14}\end{array}$ \\
\hline & Mine & $\begin{array}{l}5.4 \times 10^{-10} \\
6.8 \times 10^{-12}\end{array}$ & $\begin{array}{l}1.3 \times 10^{-8} \\
1.6 \times 10^{-10}\end{array}$ & $\begin{array}{l}2.1 \times 10^{-3} \\
2.6 \times 10^{-5}\end{array}$ & $\begin{array}{l}7.4 \times 10^{-10} \\
9.3 \times 10^{-12}\end{array}$ & $\begin{array}{l}1.8 \times 10^{-8} \\
2.2 \times 10^{-10}\end{array}$ & $\begin{array}{l}2.9 \times 10^{-3} \\
3.6 \times 10^{-5}\end{array}$ \\
\hline
\end{tabular}




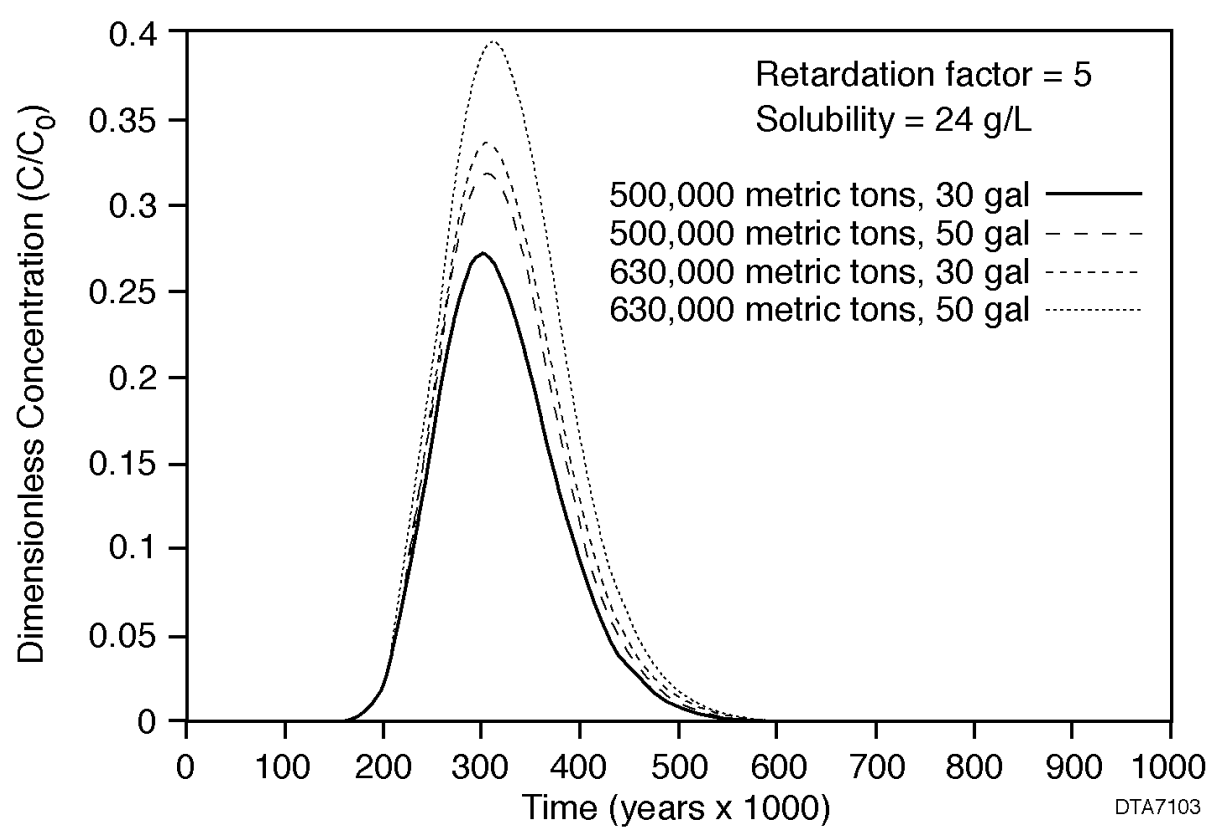

FIGURE 3 Breakthrough Curves for a Trench for a Fairly Mobile, Very Soluble Uranium Complex

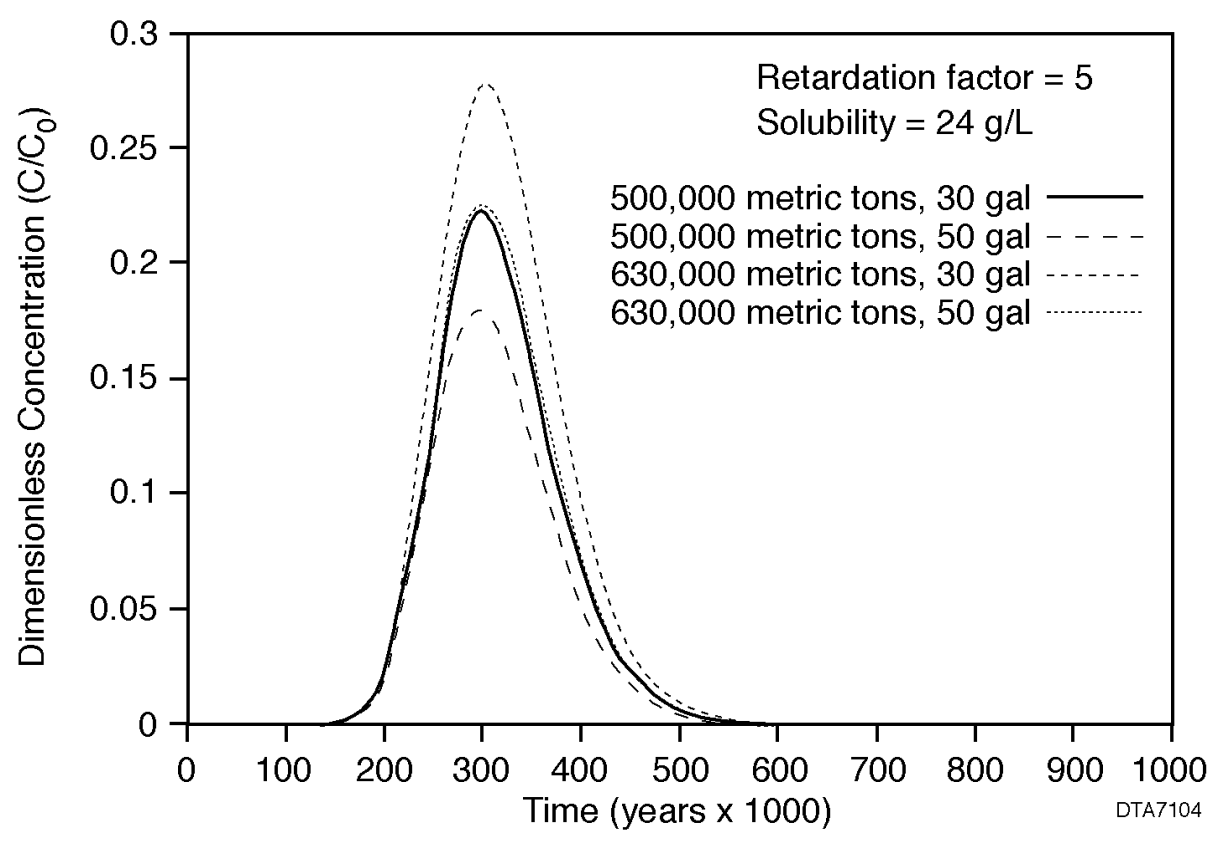

FIGURE 4 Breakthrough Curves for a Vault for a Fairly Mobile, Very Soluble Uranium Complex 


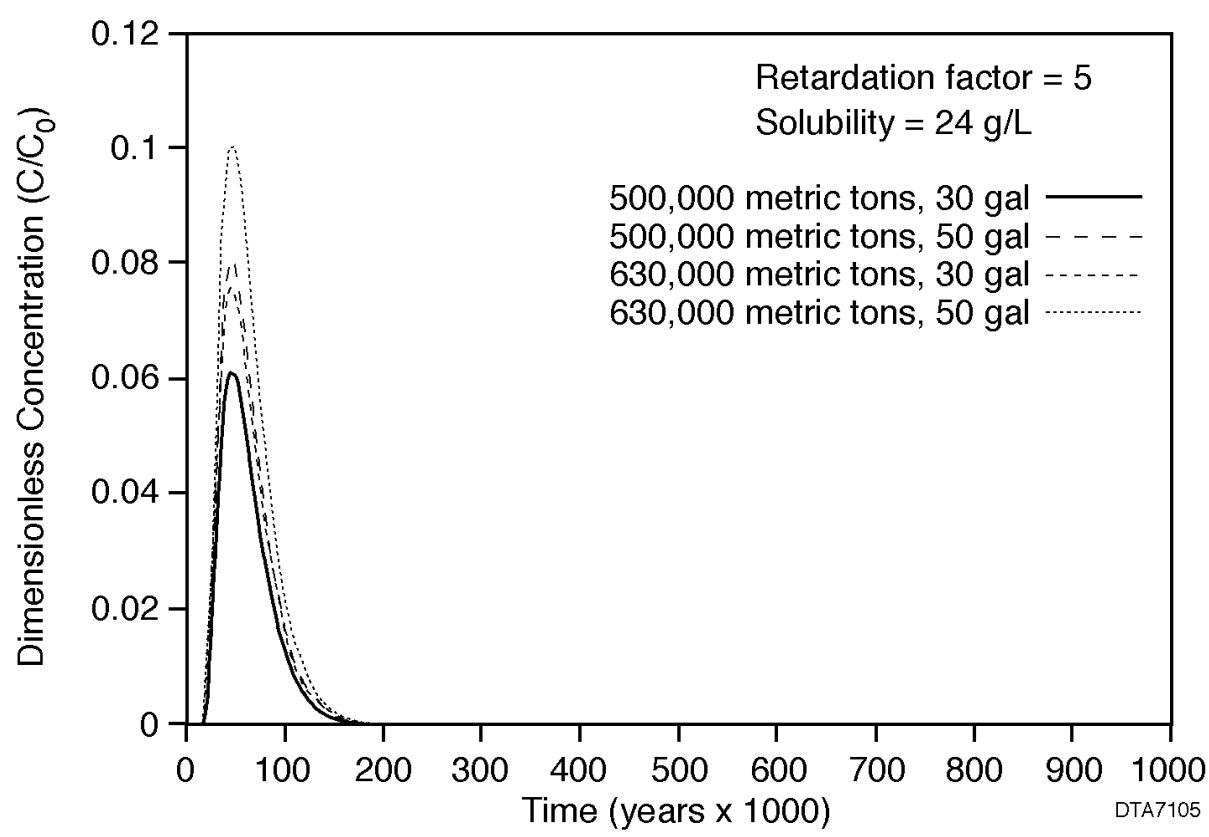

FIGURE 5 Breakthrough Curves for a Mine for a Fairly Mobile, Very Soluble Uranium Complex

concentration, 0.06 , would occur for a mine after about 60,000 years. For an initial source term concentration of $24 \mathrm{~g} / \mathrm{L}$, the maximum concentration would be $1.4 \mathrm{~g} / \mathrm{L}$.

In order to estimate the activity concentration for the highly soluble uranium complex, its chemical composition must be known. The actual chemical composition and also the solubility of this compound are site-specific parameters that depend on the geochemistry present. For the present calculations, the highly soluble uranium complex is assumed to be $\left(\mathrm{NH}_{4}\right)_{4}\left[\mathrm{UO}_{2}\left(\mathrm{CO}_{3}\right)\right]_{3}$.

The specific activity, $S A$, of a carrier-free radionuclide (i.e., one that does not contain any other isotopes of the radionuclide) can be estimated by using the following relationship (Cember 1989):

$$
S A=\frac{4.18 \times 10^{23}}{A t_{1 / 2} 3.3 \times 10^{10}}
$$

where $A$ is the molecular weight of the compound and $t_{1 / 2}$ is its half life in seconds. For a molecular weight of $492 \mathrm{~g} / \mathrm{mole}$, the specific activity of the highly soluble uranium complex is approximately $1.6 \times 10^{-7} \mathrm{Ci} / \mathrm{g}$. For this specific activity, the maximum uranium activity concentrations at the water table for a retardation of 5 would all be very large, exceeding 160,000 pCi/L (Table 4). 
If the highly soluble uranium complex is significantly retarded (retardation of 50), the maximum uranium concentrations at the water table would be smaller than those discussed above (Table 4 and Figures 6 through 8). For this case, the largest dimensionless concentration, 0.043, would occur after 2.9 million years for a failed trench in which 500,000 $\mathrm{t}$ of $\mathrm{UF}_{4}$ were disposed of in 30-gal drums. The smallest maximum dimensionless concentration, 0.006, would occur after 450,000 years for a failed mine in which $500,000 \mathrm{t}$ of $\mathrm{UF}_{4}$ were disposed of in 30-gal drums. Although these dimensionless concentrations are less than 1.0, the uranium activity concentrations would still be very large, exceeding 22,000 pCi/L.

Although the maximum uranium activity concentrations at the water table would be very large for any of the scenarios, dimensionless concentrations, actual concentrations, and activity concentrations after 1,000 years would be very small (Table 5). For a fairly mobile form of highly soluble uranium (retardation of 5), the maximum activity concentration would be $2.9 \times 10^{-3} \mathrm{pCi} / \mathrm{L}$ for a failed mine in which 630,000 t of $\mathrm{UF}_{4}$ were disposed of in 50-gal drums. For a retardation of 50 , the maximum activity concentration of uranium after 1,000 years would be $3.6 \times 10^{-5} \mathrm{pCi} / \mathrm{L}$, once again for a failed mine in which $630,000 \mathrm{t}$ of $\mathrm{UF}_{4}$ were disposed of in 50-gal drums.

If the form of uranium released was fairly mobile schoepite, the maximum activity concentration at the water table after 1,000 years would be $2.3 \times 10^{-6} \mathrm{pCi} / \mathrm{L}$ for disposing of the $\mathrm{UF}_{4}$ in a mine. This value would be independent of the size of the storage container or the total mass that was disposed of because of the very long duration of the source.

All of the above estimated concentrations and activity concentrations were values for water within the unsaturated soil column. At the water table, additional dilution will occur when the contaminated water from the unsaturated enters the zone of saturation and mixes with initially clean water. The amount of dilution, $D_{f}$, can be estimated with the following expression (Tomasko 1997a):

$$
D_{f}=\frac{V_{d} T}{I L \Phi_{v}}+1
$$

where

$$
\begin{aligned}
I= & \text { rate of water infiltration, } \\
L= & \begin{array}{l}
\text { length of the disposal cell footprint parallel for the direction of } \\
\text { groundwater flow, }
\end{array} \\
T= & \text { thickness of the saturated zone of groundwater, and } \\
\Phi_{v}= & \text { porosity or water content of the unsaturated zone. }
\end{aligned}
$$




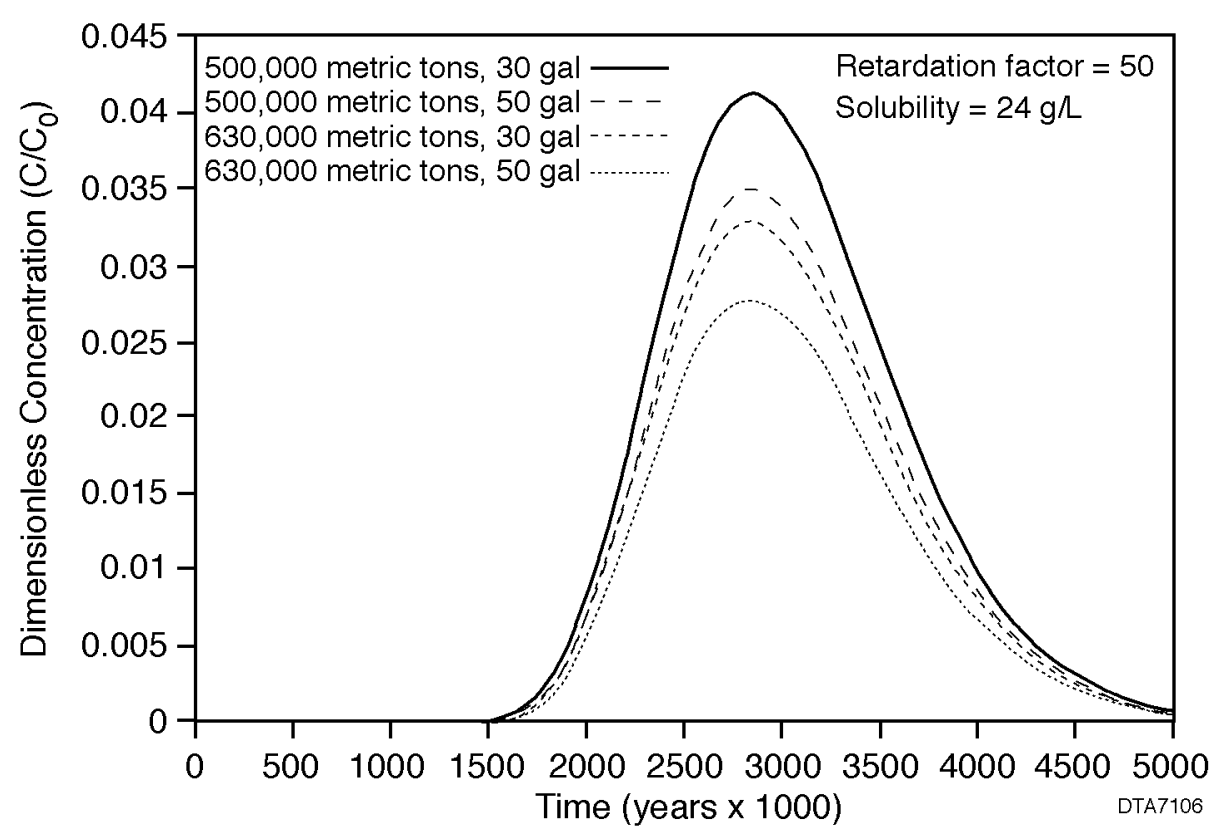

FIGURE 6 Breakthrough Curves for a Trench for a Fairly Immobile, Very Soluble Uranium Complex

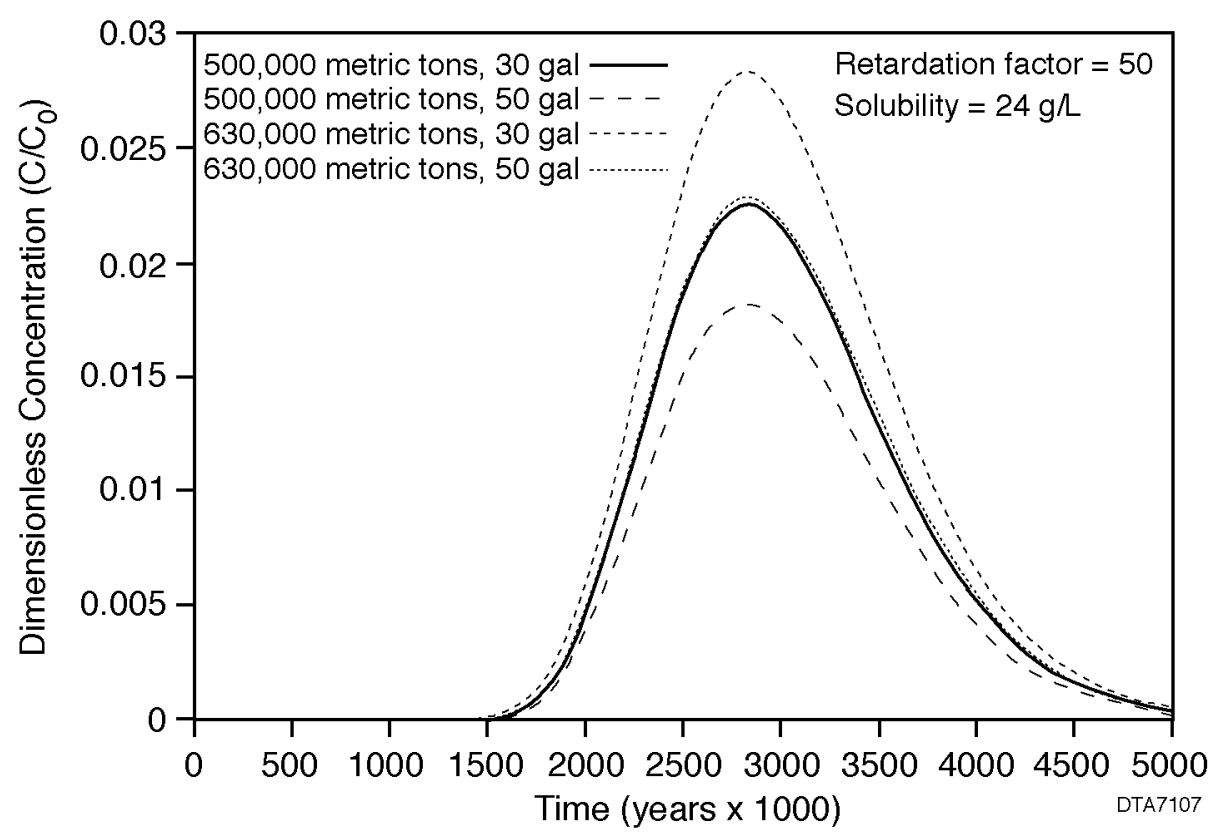

FIGURE 7 Breakthrough Curves for a Vault for a Fairly Immobile, Very Soluble Uranium Complex 


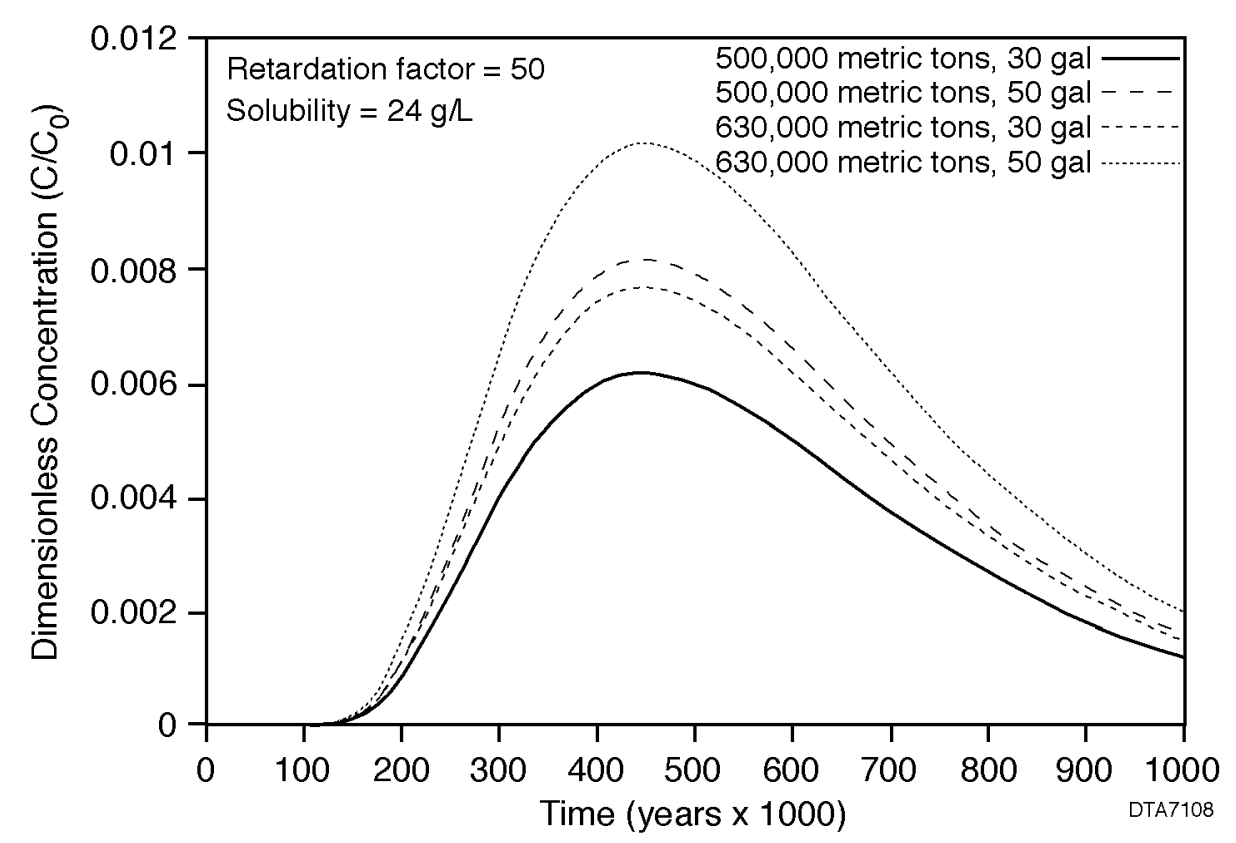

\section{FIGURE 8 Breakthrough Curves for a Mine for a Fairly Immobile,} Very Soluble Uranium Complex

The magnitude of the Darcy velocity, $V_{d}$, in Equation 7 is given by the following expression (Freeze and Cherry 1979):

$$
V_{d}=K \nabla h
$$

where $K$ is the hydraulic conductivity of the saturated zone of groundwater and $\nabla h$ is the local hydraulic gradient present (change in water level with distance).

In order to estimate the amount of dilution at the water table, the length of the disposal facility parallel to the direction of groundwater flow is required. As indicated in Table 1, each of the alternative disposal facilities (trench, vault, and mine) has a footprint area that is a function of the number of drums required for disposing of the $\mathrm{UF}_{4}$. For the present calculations, the footprints are assumed to be square and oriented with two of their opposite sides parallel to the direction of groundwater flow. The length of the facility parallel to the direction of groundwater flow is then equal to the square root of the footprint area (Table 6).

In addition to the lengths of the disposal facilities parallel to the direction of groundwater flow, the magnitude of the Darcy velocity is required. For a hydraulic conductivity of 11,000 ft/yr and a hydraulic gradient of 0.001 (Table 3), the magnitude of the Darcy velocity is $11 \mathrm{ft} / \mathrm{yr}$. For a 
TABLE 6 Lengths of Disposal Cell Footprint (in meters) Parallel to the Direction of Groundwater Flow

\begin{tabular}{|c|c|c|c|c|}
\hline \multirow[b]{2}{*}{ Facility } & \multicolumn{2}{|c|}{$500,000 \mathrm{t}$} & \multicolumn{2}{|c|}{$630,000 \mathrm{t}$} \\
\hline & 30-gal Drums & 50-gal Drums & 30-gal Drums & 50-gal Drums \\
\hline Trench & 454 & 417 & 505 & 465 \\
\hline Vault & 504 & 562 & 562 & 616 \\
\hline Mine & 1,570 & 1,370 & 1,760 & 1,530 \\
\hline
\end{tabular}

TABLE 7 Dilution Factors for Mixing at the Water Table

\begin{tabular}{lccccc}
\hline & \multicolumn{2}{c}{$500,000 \mathrm{t}$} & & \multicolumn{2}{c}{$630,000 \mathrm{t}$} \\
\cline { 2 - 3 } \cline { 5 - 6 } Facility & 30 -gal Drums & 50 -gal Drums & & 30 -gal Drums & 50 -gal Drums \\
\hline & & & & 797 & 865 \\
Trench & 885 & 964 & 716 & 653 \\
Vault & 798 & 716 & 229 & 262 \\
Mine & 256 & 294 & & \\
\hline
\end{tabular}

saturated zone thickness of $100 \mathrm{ft}$, an infiltration velocity of $0.1 \mathrm{in} . / \mathrm{yr}$, and a porosity of 0.1 (Table 3), the dilution factors for the three disposal facilities are given in Table 7. The dilution factor ranges from 229 for disposing of 630,000 $\mathrm{t}$ of $\mathrm{UF}_{4}$ in a mine to 964 for disposing of 500,000 $\mathrm{t}$ of $\mathrm{UF}_{4}$ in a trench in 50-gal drums. In general, the larger the facility (i.e., length of the disposal facility in a direction parallel to the direction of groundwater flow), the smaller the amount of dilution. A summary of concentration and activity concentrations after 1,000 years after mixing with initially clean water in the saturated zone is given in Table 8; maximum concentrations and activity concentrations after dilution are given in Table 9. 
TABLE 8 Summary of Concentrations at 1,000 Years after Dilution at the Water Table

\begin{tabular}{|c|c|c|c|c|c|c|c|}
\hline \multirow[b]{2}{*}{$\begin{array}{c}\text { Solubility } \\
(\mathrm{g} / \mathrm{L})\end{array}$} & \multirow[b]{2}{*}{ Facility } & \multicolumn{3}{|c|}{$500,000 \mathrm{t}$ in 30 -gal Drums } & \multicolumn{3}{|c|}{$500,000 \mathrm{t}$ in 50 -gal Drums } \\
\hline & & $C / C_{0}$ & $\begin{array}{c}\text { Concentration } \\
(\mathrm{g} / \mathrm{L})\end{array}$ & $\begin{array}{c}\text { Activity } \\
\text { Concentration } \\
(\mathrm{pCi} / \mathrm{L})\end{array}$ & $C / C_{0}$ & $\begin{array}{c}\text { Concentration } \\
(\mathrm{g} / \mathrm{L})\end{array}$ & $\begin{array}{c}\text { Activity } \\
\text { Concentration } \\
(\mathrm{pCi} / \mathrm{L})\end{array}$ \\
\hline \multirow[t]{3}{*}{$2.4 \times 10^{-3}$} & Trench & $\begin{array}{l}2.4 \times 10^{-12} \\
6.9 \times 10^{-24}\end{array}$ & $\begin{array}{l}5.8 \times 10^{-15} \\
1.7 \times 10^{-26}\end{array}$ & $\begin{array}{l}1.4 \times 10^{-9} \\
4.1 \times 10^{-21}\end{array}$ & $\begin{array}{l}2.2 \times 10^{-12} \\
6.3 \times 10^{-24}\end{array}$ & $\begin{array}{l}5.2 \times 10^{-15} \\
1.6 \times 10^{-26}\end{array}$ & $\begin{array}{l}1.2 \times 10^{-9} \\
3.7 \times 10^{-21}\end{array}$ \\
\hline & Vault & $\begin{array}{l}2.6 \times 10^{-12} \\
7.6 \times 10^{-24}\end{array}$ & $\begin{array}{l}6.3 \times 10^{-15} \\
1.9 \times 10^{-26}\end{array}$ & $\begin{array}{l}1.5 \times 10^{-9} \\
4.5 \times 10^{-21}\end{array}$ & $\begin{array}{l}2.9 \times 10^{-12} \\
8.5 \times 10^{-24}\end{array}$ & $\begin{array}{l}7.0 \times 10^{-15} \\
2.1 \times 10^{-26}\end{array}$ & $\begin{array}{l}1.7 \times 10^{-9} \\
5.0 \times 10^{-21}\end{array}$ \\
\hline & Mine & $\begin{array}{l}1.5 \times 10^{-11} \\
6.6 \times 10^{-12}\end{array}$ & $\begin{array}{l}3.7 \times 10^{-14} \\
1.6 \times 10^{-14}\end{array}$ & $\begin{array}{l}9.0 \times 10^{-9} \\
3.8 \times 10^{-9}\end{array}$ & $\begin{array}{l}1.3 \times 10^{-11} \\
5.8 \times 10^{-12}\end{array}$ & $\begin{array}{l}3.2 \times 10^{-14} \\
1.4 \times 10^{-14}\end{array}$ & $\begin{array}{l}7.8 \times 10^{-9} \\
3.3 \times 10^{-9}\end{array}$ \\
\hline \multirow[t]{3}{*}{24} & Trench & $\begin{array}{l}2.2 \times 10^{-14} \\
3.8 \times 10^{-24}\end{array}$ & $\begin{array}{l}5.1 \times 10^{-13} \\
9.2 \times 10^{-23}\end{array}$ & $\begin{array}{l}8.1 \times 10^{-8} \\
1.5 \times 10^{-17}\end{array}$ & $\begin{array}{l}2.0 \times 10^{-14} \\
3.5 \times 10^{-24}\end{array}$ & $\begin{array}{l}4.7 \times 10^{-13} \\
8.5 \times 10^{-23}\end{array}$ & $\begin{array}{l}7.5 \times 10^{-8} \\
1.4 \times 10^{-17}\end{array}$ \\
\hline & Vault & $\begin{array}{l}2.8 \times 10^{-14} \\
3.8 \times 10^{-24}\end{array}$ & $\begin{array}{l}6.6 \times 10^{-13} \\
9.0 \times 10^{-23}\end{array}$ & $\begin{array}{l}1.1 \times 10^{-7} \\
1.5 \times 10^{-17}\end{array}$ & $\begin{array}{l}3.1 \times 10^{-14} \\
4.2 \times 10^{-24}\end{array}$ & $\begin{array}{l}7.4 \times 10^{-13} \\
1.0 \times 10^{-22}\end{array}$ & $\begin{array}{l}1.2 \times 10^{-7} \\
1.6 \times 10^{-17}\end{array}$ \\
\hline & Mine & $\begin{array}{l}2.2 \times 10^{-12} \\
2.2 \times 10^{-14}\end{array}$ & $\begin{array}{l}5.5 \times 10^{-11} \\
5.1 \times 10^{-13}\end{array}$ & $\begin{array}{l}8.6 \times 10^{-6} \\
8.2 \times 10^{-8}\end{array}$ & $\begin{array}{l}1.9 \times 10^{-12} \\
1.9 \times 10^{-14}\end{array}$ & $4.6 \times 10^{-11}-13$ & $\begin{array}{l}7.4 \times 10^{-6} \\
7.2 \times 10^{-8}\end{array}$ \\
\hline & & \multicolumn{3}{|c|}{$630,000 \mathrm{t}$ in 30 -gal drums } & \multicolumn{3}{|c|}{$630,000 \mathrm{t}$ in 50 -gal drums } \\
\hline $\begin{array}{c}\text { Solubility } \\
(\mathrm{g} / \mathrm{L})\end{array}$ & Facility & $C / C_{0}$ & $\begin{array}{c}\text { Concentration } \\
(\mathrm{g} / \mathrm{L})\end{array}$ & $\begin{array}{c}\text { Activity } \\
\text { Concentration } \\
(\mathrm{pCi} / \mathrm{L})\end{array}$ & $C / C_{0}$ & Concentration & $\begin{array}{c}\text { Activity } \\
\text { Concentration }\end{array}$ \\
\hline \multirow[t]{3}{*}{$2.4 \times 10^{-3}$} & Trench & $\begin{array}{l}2.6 \times 10^{-12} \\
7.7 \times 10^{-24}\end{array}$ & $\begin{array}{l}6.3 \times 10^{-15} \\
1.9 \times 10^{-26}\end{array}$ & $\begin{array}{l}1.5 \times 10^{-9} \\
4.5 \times 10^{-21}\end{array}$ & $\begin{array}{l}2.4 \times 10^{-12} \\
7.1 \times 10^{-24}\end{array}$ & $\begin{array}{l}5.8 \times 10^{-15} \\
1.7 \times 10^{-26}\end{array}$ & $\begin{array}{l}1.4 \times 10^{-9} \\
4.2 \times 10^{-21}\end{array}$ \\
\hline & Vault & $\begin{array}{l}2.9 \times 10^{-12} \\
7.7 \times 10^{-24}\end{array}$ & $\begin{array}{l}7.0 \times 10^{-15} \\
5.0 \times 10^{-21}\end{array}$ & $\begin{array}{l}1.7 \times 10^{-9} \\
1.2 \times 10^{-15}\end{array}$ & $\begin{array}{l}3.2 \times 10^{-12} \\
9.3 \times 10^{-24}\end{array}$ & $\begin{array}{l}7.7 \times 10^{-15} \\
2.3 \times 10^{-26}\end{array}$ & $\begin{array}{l}1.8 \times 10^{-9} \\
5.5 \times 10^{-21}\end{array}$ \\
\hline & Mine & $\begin{array}{l}1.7 \times 10^{-11} \\
7.4 \times 10^{-12}\end{array}$ & $\begin{array}{l}4.1 \times 10^{-14} \\
1.8 \times 10^{-14}\end{array}$ & $\begin{array}{l}1.0 \times 10^{-8} \\
4.2 \times 10^{-9}\end{array}$ & $\begin{array}{l}1.5 \times 10^{-11} \\
6.5 \times 10^{-12}\end{array}$ & $\begin{array}{l}3.6 \times 10^{-14} \\
1.5 \times 10^{-14}\end{array}$ & $\begin{array}{l}8.8 \times 10^{-9} \\
3.7 \times 10^{-9}\end{array}$ \\
\hline \multirow[t]{3}{*}{24} & Trench & $\begin{array}{l}2.3 \times 10^{-14} \\
4.8 \times 10^{-24}\end{array}$ & $\begin{array}{l}5.5 \times 10^{-13} \\
1.1 \times 10^{-22}\end{array}$ & $\begin{array}{l}8.9 \times 10^{-8} \\
1.8 \times 10^{-17}\end{array}$ & $\begin{array}{l}2.1 \times 10^{-14} \\
4.4 \times 10^{-24}\end{array}$ & $\begin{array}{l}5.0 \times 10^{-13} \\
1.1 \times 10^{-22}\end{array}$ & $\begin{array}{l}8.0 \times 10^{-8} \\
1.8 \times 10^{-17}\end{array}$ \\
\hline & Vault & $\begin{array}{l}2.8 \times 10^{-14} \\
4.8 \times 10^{-24}\end{array}$ & $\begin{array}{l}6.6 \times 10^{-13} \\
1.2 \times 10^{-22}\end{array}$ & $\begin{array}{l}1.1 \times 10^{-7} \\
1.8 \times 10^{-17}\end{array}$ & $\begin{array}{l}3.1 \times 10^{-14} \\
5.2 \times 10^{-24}\end{array}$ & $\begin{array}{l}7.4 \times 10^{-13} \\
1.3 \times 10^{-22}\end{array}$ & $\begin{array}{l}1.2 \times 10^{-7} \\
2.1 \times 10^{-17}\end{array}$ \\
\hline & Mine & $\begin{array}{l}2.4 \times 10^{-12} \\
3.0 \times 10^{-14}\end{array}$ & $\begin{array}{l}5.7 \times 10^{-11} \\
7.0 \times 10^{-13}\end{array}$ & $\begin{array}{l}9.2 \times 10^{-6} \\
1.1 \times 10^{-7}\end{array}$ & $\begin{array}{l}2.1 \times 10^{-12} \\
2.6 \times 10^{-14} \\
\end{array}$ & $\begin{array}{l}5.0 \times 10^{-11} \\
6.2 \times 10^{-13}\end{array}$ & $\begin{array}{l}8.0 \times 10^{-6} \\
9.9 \times 10^{-8}\end{array}$ \\
\hline
\end{tabular}


TABLE 9 Maximum Concentrations and Occurrence Times for Long-Term Disposal of UF after Dilution

\begin{tabular}{|c|c|c|c|c|c|c|c|c|}
\hline \multirow[b]{2}{*}{$\begin{array}{l}\text { Solubility } \\
\text { (g/L) }\end{array}$} & \multirow[b]{2}{*}{$\mathrm{R}^{\mathrm{a}}$} & \multirow[b]{2}{*}{ Facility } & \multicolumn{3}{|c|}{$500,000 \mathrm{t}$ in 30 -gal Drums } & \multicolumn{3}{|c|}{$500,000 \mathrm{t}$ in 50 -gal Drums } \\
\hline & & & $C / C_{0}$ & $\begin{array}{c}\text { Concentration } \\
(\mathrm{g} / \mathrm{L})\end{array}$ & $\begin{array}{c}\text { Activity } \\
\text { Concentration } \\
(\mathrm{pCi} / \mathrm{L})\end{array}$ & $C / C_{0}$ & $\begin{array}{c}\text { Concentration } \\
(\mathrm{g} / \mathrm{L})\end{array}$ & $\begin{array}{c}\text { Activity } \\
\text { Concentration } \\
(\mathrm{pCi} / \mathrm{L})\end{array}$ \\
\hline \multirow[t]{6}{*}{$2.4 \times 10^{-3}$} & 5 & Trench & $1.1 \times 10^{-3}$ & $2.7 \times 10^{-6}$ & 0.7 & $1.0 \times 10^{-3}$ & $2.4 \times 10^{-6}$ & 0.6 \\
\hline & & Vault & $\begin{array}{l}550,000 \mathrm{yr} \\
1.3 \times 10^{-3} \\
550,000 \mathrm{yr}\end{array}$ & $3.0 \times 10^{-6}$ & 0.7 & $\begin{array}{l}550,000 \mathrm{yr} \\
1.4 \times 10^{-3} \\
550,000 \mathrm{yr}\end{array}$ & $2.4 \times 10^{-3}$ & 0.8 \\
\hline & & Mine & $\begin{array}{l}3.9 \times 10^{-3} \\
200,000 \mathrm{yr}\end{array}$ & $9.4 \times 10^{-6}$ & 2.3 & $\begin{array}{l}3.4 \times 10^{-3} \\
200,000 \mathrm{yr}\end{array}$ & $8.2 \times 10^{-6}$ & 2.0 \\
\hline & 50 & Trench & $\begin{array}{l}1.1 \times 10^{-3} \\
5,000,000 \mathrm{yr}\end{array}$ & $2.7 \times 10^{-6}$ & 0.7 & $\begin{array}{l}1.1 \times 10^{-3} \\
5,000,000 \mathrm{yr}\end{array}$ & $2.4 \times 10^{-6}$ & 0.6 \\
\hline & & Vault & $\begin{array}{l}1.3 \times 10^{-3} \\
5,000,000 \mathrm{yr}\end{array}$ & $3.0 \times 10^{-6}$ & 0.7 & $\begin{array}{l}1.3 \times 10^{-3} \\
5,000,000 \mathrm{yr}\end{array}$ & $2.4 \times 10^{-3}$ & 0.8 \\
\hline & & Mine & $\begin{array}{l}3.9 \times 10^{-3} \\
2,000,000 \mathrm{yr}\end{array}$ & $9.4 \times 10^{-6}$ & 2.3 & $\begin{array}{l}3.9 \times 10^{-3} \\
2,000,000 \mathrm{yr}\end{array}$ & $8.2 \times 10^{-6}$ & 2.0 \\
\hline \multirow[t]{6}{*}{24} & 5 & Trench & $\begin{array}{l}3.1 \times 10^{-4} \\
310,000 \mathrm{yr}\end{array}$ & $7.3 \times 10^{-3}$ & 1,170 & $\begin{array}{l}3.3 \times 10^{-4} \\
315,000 \mathrm{yr}\end{array}$ & $8.0 \times 10^{-3}$ & 1,270 \\
\hline & & Vault & $\begin{array}{l}2.8 \times 10^{-4} \\
305,000 \mathrm{yr}\end{array}$ & $6.6 \times 10^{-3}$ & 1,060 & $\begin{array}{l}2.5 \times 10^{-4} \\
300,000 \mathrm{yr}\end{array}$ & $6.0 \times 10^{-3}$ & 965 \\
\hline & & Mine & $\begin{array}{l}2.3 \times 10^{-4} \\
60,000 \mathrm{yr}\end{array}$ & $5.6 \times 10^{-3}$ & 900 & $\begin{array}{l}2.7 \times 10^{-4} \\
65,000 \mathrm{yr}\end{array}$ & $6.5 \times 10^{-3}$ & 1,040 \\
\hline & 50 & Trench & $\begin{array}{l}4.9 \times 10^{-5} \\
2,900,000 \mathrm{yr}\end{array}$ & $1.2 \times 10^{-3}$ & 187 & $\begin{array}{l}3.7 \times 10^{-5} \\
2,850,000 \mathrm{yr}\end{array}$ & $9.0 \times 10^{-4}$ & 143 \\
\hline & & Vault & $\begin{array}{l}2.8 \times 10^{-5} \\
2,850,000 \mathrm{yr}\end{array}$ & $6.6 \times 10^{-4}$ & 106 & $\begin{array}{l}2.8 \times 10^{-5} \\
2,800,000 \mathrm{yr}\end{array}$ & $5.7 \times 10^{-4}$ & 91 \\
\hline & & Mine & $\begin{array}{l}2.3 \times 10^{-5} \\
4 \underline{50,000} \mathrm{yr}\end{array}$ & $5.6 \times 10^{-4}$ & 90 & $2.8 \times 10^{-5}$ & $6.7 \times 10^{-4}$ & 107 \\
\hline \multirow[b]{2}{*}{$\begin{array}{l}\text { Solubility } \\
\text { (g/L) }\end{array}$} & \multirow[b]{2}{*}{$\mathrm{R}^{\mathrm{a}}$} & & \multicolumn{3}{|c|}{$630,000 \mathrm{t}$ in 30 -gal Drums } & \multicolumn{3}{|c|}{$630,000 \mathrm{t}$ in 50 -gal Drums } \\
\hline & & Facility & $C / C_{0}$ & $\begin{array}{c}\text { Concentration } \\
(\mathrm{g} / \mathrm{L})\end{array}$ & $\begin{array}{c}\text { Activity } \\
\text { Concentration } \\
(\mathrm{pCi} / \mathrm{L})\end{array}$ & $C / C_{0}$ & $\begin{array}{c}\text { Concentration } \\
(\mathrm{g} / \mathrm{L})\end{array}$ & $\begin{array}{c}\text { Activity } \\
\text { Concentration } \\
(\mathrm{pCi} / \mathrm{L})\end{array}$ \\
\hline \multirow[t]{6}{*}{$2.4 \times 10^{-3}$} & 5 & Trench & $\begin{array}{l}1.3 \times 10^{-3} \\
550,000 \mathrm{yr}\end{array}$ & $3.0 \times 10^{-6}$ & 0.7 & $\begin{array}{l}1.2 \times 10^{-3} \\
550,000 \mathrm{yr}\end{array}$ & $2.8 \times 10^{-6}$ & 0.7 \\
\hline & & Vault & $\begin{array}{l}1.4 \times 10^{-3} \\
550,000 \mathrm{yr}\end{array}$ & $3.4 \times 10^{-6}$ & 0.8 & $\begin{array}{l}1.5 \times 10^{-3} \\
550,000 \mathrm{yr}\end{array}$ & $3.7 \times 10^{-6}$ & 0.9 \\
\hline & & Mine & $\begin{array}{l}4.4 \times 10^{-3} \\
200,000 \mathrm{yr}\end{array}$ & $1.1 \times 10^{-5}$ & 2.5 & $\begin{array}{l}3.8 \times 10^{-3} \\
200,000 \mathrm{yr}\end{array}$ & $9.2 \times 10^{-6}$ & 2.2 \\
\hline & 50 & Trench & $\begin{array}{l}1.3 \times 10^{-3} \\
5,000,000 \mathrm{yr}\end{array}$ & $3.0 \times 10^{-6}$ & 0.7 & $\begin{array}{l}1.2 \times 10^{-3} \\
5,000,000 \mathrm{yr}\end{array}$ & $2.8 \times 10^{-6}$ & 0.7 \\
\hline & & Vault & $\begin{array}{l}1.4 \times 10^{-3} \\
5,000,000 \mathrm{yr}\end{array}$ & $3.4 \times 10^{-6}$ & 0.8 & $\begin{array}{l}1.5 \times 10^{-3} \\
5,000,000 \mathrm{yr}\end{array}$ & $3.7 \times 10^{-6}$ & 0.9 \\
\hline & & Mine & $\begin{array}{l}4.4 \times 10^{-3} \\
2,000,000 \mathrm{yr}\end{array}$ & $1.1 \times 10^{-5}$ & 2.5 & $\begin{array}{l}3.8 \times 10^{-3} \\
2,000,000 \mathrm{yr}\end{array}$ & $9.2 \times 10^{-6}$ & 2.2 \\
\hline
\end{tabular}


TABLE 9 (Cont.)

\begin{tabular}{|c|c|c|c|c|c|c|c|c|}
\hline \multirow[b]{2}{*}{$\begin{array}{l}\text { Solubility } \\
(\mathrm{g} / \mathrm{L})\end{array}$} & \multirow[b]{2}{*}{$\mathrm{R}^{\mathrm{a}}$} & \multirow[b]{2}{*}{ Facility } & \multicolumn{3}{|c|}{$630,000 \mathrm{t}$ in 30 -gal Drums } & \multicolumn{3}{|c|}{$630,000 \mathrm{t}$ in 50 -gal Drums } \\
\hline & & & $C / C_{0}$ & $\begin{array}{c}\text { Concentration } \\
(\mathrm{g} / \mathrm{L})\end{array}$ & $\begin{array}{c}\text { Activity } \\
\text { Concentration } \\
(\mathrm{pCi} / \mathrm{L})\end{array}$ & $C / C_{0}$ & $\begin{array}{c}\text { Concentration } \\
(\mathrm{g} / \mathrm{L})\end{array}$ & $\begin{array}{c}\text { Activity } \\
\text { Concentration } \\
(\mathrm{pCi} / \mathrm{L})\end{array}$ \\
\hline \multirow[t]{6}{*}{24} & 5 & Trench & $\begin{array}{l}4.3 \times 10^{-4} \\
310,000 \mathrm{yr}\end{array}$ & $1.0 \times 10^{-2}$ & 1,640 & $\begin{array}{l}4.5 \times 10^{-4} \\
315,000 \mathrm{yr}\end{array}$ & $1.1 \times 10^{-2}$ & 1,730 \\
\hline & & Vault & $\begin{array}{l}3.9 \times 10^{-4} \\
310,000 \mathrm{yr}\end{array}$ & $9.4 \times 10^{-3}$ & 1,500 & $\begin{array}{l}3.5 \times 10^{-4} \\
308,000 \mathrm{yr}\end{array}$ & $8.5 \times 10^{-3}$ & 1,350 \\
\hline & & Mine & $\begin{array}{l}3.3 \times 10^{-4} \\
65,000 \mathrm{yr}\end{array}$ & $7.9 \times 10^{-3}$ & 1,260 & $\begin{array}{l}3.8 \times 10^{-4} \\
75,000 \mathrm{yr}\end{array}$ & $9.2 \times 10^{-3}$ & 1,470 \\
\hline & 50 & Trench & $\begin{array}{l}4.1 \times 10^{-5} \\
2,800,000 \mathrm{yr}\end{array}$ & $9.9 \times 10^{-4}$ & 159 & $\begin{array}{l}3.2 \times 10^{-5} \\
2,700,000 \mathrm{yr}\end{array}$ & $7.8 \times 10^{-4}$ & 124 \\
\hline & & Vault & $\begin{array}{l}3.9 \times 10^{-5} \\
2,900,000 \mathrm{yr}\end{array}$ & $9.4 \times 10^{-4}$ & 150 & $\begin{array}{l}3.5 \times 10^{-5} \\
2,870,000 \mathrm{yr}\end{array}$ & $8.3 \times 10^{-4}$ & 132 \\
\hline & & Mine & $\begin{array}{l}3.3 \times 10^{-5} \\
452,000 \mathrm{yr}\end{array}$ & $7.9 \times 10^{-4}$ & 126 & $\begin{array}{l}3.8 \times 10^{-5} \\
452,000 \mathrm{yr}\end{array}$ & $9.2 \times 10^{-4}$ & 147 \\
\hline
\end{tabular}

a $\mathrm{R}=$ retardation factor. 


\section{DISCUSSION}

As indicated in Table 8, all of the contaminant concentrations and activity concentrations at the water table would be very low, even for a fairly mobile compound (retardation of 5). In general, the concentrations after 1,000 years at the water table would be about an order of magnitude greater for disposal in a deep mine than for disposal in a trench or vault.

Out of all the options and potential contaminants considered in this study, the largest activity concentration at the water table after 1,000 years would be derived from a failed mine that released a fairly mobile and highly soluble uranium complex. This concentration would be about $8.6 \times 10^{-6} \mathrm{pCi} / \mathrm{L}$ for $500,000 \mathrm{t}$ of $\mathrm{UF}_{4}$ disposed of in 30-gal drums. The smallest activity concentrations at the water table after 1,000 years would, in general, be derived from a failed trench $\left(1.2 \times 10^{-9} \mathrm{pCi} / \mathrm{L}\right)$, if the contaminant reached the water table as schoepite.

Although all the activity concentrations at the water table after 1,000 years are predicted to be small, maximum activity concentrations could still be large, even after dilution (Table 9). Maximum activity concentrations of uranium would exceed $900 \mathrm{pCi} / \mathrm{L}$ for a failed disposal facility if a highly soluble uranium complex formed and if this compound was fairly mobile in the groundwater system. If the solubility of the uranium compound was small $\left(2.4 \times 10^{-3} \mathrm{~g} / \mathrm{L}\right)$, the resulting uranium activity concentrations would be small, less than $2.5 \mathrm{pCi} / \mathrm{L}$. 


\section{REFERENCES}

Bear, J., 1972, Dynamics of Fluids in Porous Media, American Elsevier Publishing Company, New York, N.Y.

Cember, H., 1989, Introduction to Health Physics, Pergamon Press, New York, N.Y.

DOE, 1997, Programmatic Environmental Impact Statement for Alternative Strategies for the LongTerm Management and Use of Depleted Uranium Hexafluoride, Volumes 1 and 2, Office of Nuclear Energy, Science and Technology, Germantown, Md., Dec.

DOE and EPA, 1999, Understanding Variation in Partition Coefficient, $K_{d}$ Values, Volume II: Review of Geochemistry and Available $K_{d}$ Values for Cadmium, Cesium, Chromium, Lead, Plutonium, Radon, Strontium, Thorium, Tritium $\left({ }^{3} H\right)$, and Uranium, U.S. Department of Energy, Office of Environmental Restoration, and U.S. Environmental Protection Agency, Office of Solid Waste Management and Emergency Response, Washington, D.C., Aug.

Folga, S., and P. Kier, 2001, Engineering Analysis for Disposal of Depleted Uranium Tetrafluoride $\left(U F_{4}\right)$, ANL/DIS/TM-104, Argonne National Laboratory, Argonne, Ill.

Freeze, R.A., and J.A. Cherry, 1979, Groundwater, Prentice-Hall, Inc., Englewood Cliffs, N.J.

Gmelin, L., 1983, Gmelin Handbook of Inorganic Chemistry, 8th Edition, Springer-Verlag, New York, N.Y.

Hildebrand, F.B., 1976, Advanced Calculus for Applications, Prentice-Hall, Inc., Englewood Cliffs, N.J.

Kozak, M.W., et al., Performance Assessment of the Proposed Disposal of Depleted Uranium as Class A Low-Level Waste, FIN A1764, Final Letter Report, prepared by Sandia National Laboratories, Albuquerque, N.M., for the Office of Nuclear Material Safety and Safeguards, U.S. Department of Energy, Dec.

Lallemand-Barres, A., and P. Peaudecerf, 1978, "Recherche des Relations entre a Valeur de la Dispersivite Macroscopique d'un Milieu Aquifere, Ses Autres Caracteristiques et les Conditions de Mesure," Bulletin Bureau Geologique Minieres 4:277-284.

Langmuir, D., 1978, "Uranium Solution-Mineral Equilibria at Low Temperatures with Applications to Sedimentary Ore Deposits," Geochim. Cosmochim. Acta 42:547-569. 
Rice, R.C., et al., 1989, "Ionic Composition of Vadose Zone Water in an Arid Region," Ground Water 27(6):813-822.

Tomasko, D., 1997a, unpublished information on water and soil impacts to support the depleted UF 6 PEIS, Argonne National Laboratory, Argonne, Ill.

Tomasko, D., 1997b, An Analytical Model for Predicting Transport in a Coupled Vadose/Phreatic System, ANL/EAD/TM-68, Argonne National Laboratory, Argonne, Ill. 
